\title{
Impacts of Deregulation on Performance and Management of the Largest American Transportation Companies
}

\section{By: Timothy W. Ruefli}

Date: January 1986

\begin{abstract}
:
The effects of the past quarter century of deregulation on the transportation industry in the United States are many and varied. Impacts have been felt at the level of the industry as a whole, at the level of mode-based industry sub-groups, and at the level of individual firms. Analyses and depictions of these impacts have appeared in numerous books and journal articles. In this paper a new, empirically based, methodological approach to industry analysis will be employed to evaluate and illustrate the impacts of deregulation on the relevant levels of this industry in terms of its largest firms. The results of this analysis will be seen to be largely complementary to previous analyses, but will go beyond them in being able to identify in quantitative terms differential impacts of regulatory and other events on individual firms, groups of firms, and the industry from a unified methodological point of view.
\end{abstract}

A later version of this paper appeared in Technovation, volume 5, issues 1-3, October 1986, Pages 35-60, doi 10.1016/0166-4972(86)90043-X.

Keywords: transportation, deregulation

IC2 Institute Working Paper WP-1986-02-04

The University of Texas at Austin

$\mathrm{IC}^{2}$ Institute

Office of the Vice President for Research

(C) IC ${ }^{2}$ Institute, The University of Texas at Austin

http://ic2.utexas.edu 
IMPACTS OF DEREGULATION ON PERFORMANCE

AND MANAGEMENT OF THE LARGEST AMERICAN

TRANSPORTATION COMPANIES

Timothy W. Ruef1i

Rex A. and Dorothy B. Sebastian Professor

Frank C. Erwin Jr. Centennial Fellow

$$
\begin{gathered}
\mathrm{IC}^{2} \text { Institute } \\
\text { and }
\end{gathered}
$$

Graduate School of Business

The University of Texas at Austin

Working Paper 非

86-02-4

January 1986

IC ${ }^{2}$ Institute, The University of Texas, Austin, Texas

PLEASE DO NOT QUOTE OR CITE WITHOUT PERMISSION OF AUTHOR 


\section{ABSTRACT}

The effects of the past quarter-century of deregulation on the transportation industry in the United states are many and varied. impacts have been felt at the level of the Industry as a whole, at the level of mode-based industry sub-groups, and at the level of individual firms. Analyses and depictions of these impacts have appeared in numerous books and journal articles. In this paper a new, empirically based, methodological approach to Industry analysis will be employed to evaluate and lilustrate the impacts of deregulation on the relevant levels of this industry in terms of its largest firms. The results of this analysis will be seen to be largely complementary to previous analyses, but will go beyond them in being able to identify in quantitative terms differential impacts of regulatory and other events on individual firms, groups of firms, and the industry from a unified methodological point of view.

\section{INTRODUCTION}

The transportation industry has undergone substantial changes in the last quarter-century. These changes have been 
documented on a daily basis in the press, weakly in industry and news magazines, and over longer periods of time in scholarly books and journal articles cowing \& Stevenson 1981, Lieb 1981, Altshuler 1979, Spady 1979, Temple, Barker, \& Sloane 1982, Dept. of Transportation 1978). In this paper we will look at tho the transportation industry from multiple perspectives involving the top one hundred or so firms that participated in that industry over the quarter century from 1957 to 1984. Deregulation Impacted on different segments of the transportation industry at different times and in different ways. The analysis presented here will focus on those differential effects and examine their implications for management, with some additional emphasis being placed on the case of the airlines since their performance more clearly reflects the issues raised by deregulation. The analysis will be based on a new methodology that can examine the performance of firms and groups of firms from the perspective of the whole industry or from the perspective of subgroups within that industry. In particular we will compare the economic performance of the largest airline, trucking and railroad companies as groups and in terms of selected individual firms, with the performance of the largest firms in the transportation industry as a whole, and with each other at the level of groups and individual firms. The questions we will be concerned with include: Has deregulation given one transportation mode group an advantage or disadvantage over other groups? What individual firms strategies have yielded better relative performance in the 
face of deregulation and does this differ by mode type? To shed I ight on these issues a new form of industry analysis will be employed.

While there have been numerous studies of individual transportation companies in particular and of the railroad, trucking, and airline industries in general, cfor the latter, see particularly Byrnes 1985, Friedlander \& Spady 1981, Taneja 1979 \& 1980, and Mandell 1979), for the most part these approaches have relied on standard methodologies of data analysis and presentation. Although these studies are often detailed and revealing, they are beset with the problems of screening out the effects of short-term business cycle noise, and external events, e.g., the energy crisis, and. for the most part, they eschew comparisons across difterent segments of the transportation industry.

In this chapter we will use a new methodology based on the analysis of ordinal time series, i.e. rankings of firms over time, to screen out the background noise of short-term business cycles and those external events that had no differential effect on the industry in question and to permit immediate and meaningful cross-segment comparisons. While the details of this methodology are readily accessible to most managers, the emphasis here will not be on the detailsor mechanics of the methodology, rather we will be concerned with what new light a 
new methodology can shed on the important problem of the managing the impacts of deregulation on individual firms and groups of firms.

\section{METHODOLOGY}

In analyzing a system as complex as that represented by the largest transportation companies, several problems must be faced. The problems involve making comparisons across multiple dimensions, multiple time periods, multiple firms, multiple levels, all in a hierarchy of contexts, and the problem of screening out noise in the data (see Miller \& Friesen (1982)). To manage these problems we will use a technique that is based on the analysis of the rankings of firms and groups of firms over time. That is, we will take the performance data for each firm in each year along each dimension and rank that firm against all other firms. These sets of ranks are what we shall use in our analysis. This will permit us to compare the ranking of a firm based on revenue directly with its rank based on net income. We can also compare the ranks of two different firms based on their revenue and we can compare the asset rank of a firm in one year with its asset rank in any other year without having to worry about what was the rate of inflation, etc. The comparisons will thus all be relative to the behaviors of the rest of the firms in the set being examined. We can also compare the rankings of a 
firm with rankings of other firms in its industry, or with only those firms in some subgroup.

From the ranks of individual firms we can generate aggregate rank statistics at the level of the industry as a whole and also for any subgroup in the industry. At any level, use of ranks gives us a direct benchmark against which to evaluate the performance of a firm or group of firms. Any changes that affect all firms in the same fashion, say, inflation, will not show up in the analysis of the rankings, but any factors that affect firms differently, say, the reduction of regulations affecting only airlines, will, if effective and if not offset by other factors, show up in the change of rankings of airlines relative to non-airlines.

Given the rankings of the individual firms in an industry, the rankings along a particular dimension for a group of firms can be computed simply by taking the average ranking of all the firms in the group along that dimension for a given year. This is accomplished by summing up the rankings for the individual firms in the group for each year and dividing by the number of firms. Thus we can compute the average rank position of the airlines versus the railroads versus trucking firms, etc.

In addition to generating a measure of the rank position of a group of firms, we can also easily compute a measure of the 
volatility of rank shift activity for an industry or for any group of firms within the industry. This is done for each performance dimension, for each year by subtracting the rank in the previous year from the rank in the target year for each firm in the group, adding up those rank shifts without regard to whether they are negative or positive shifts, and then dividing the total by the number of firms in the group.

A third useful measure in analyzing the behavior of a group of firms is to measure the uncertainty associated with the change of rank positions. This can be accomplished by computing the relative probability of a firm staying in its present rank in the next year, shifting to a higher rank, or shifting to a lower rank. The details of this computation are presented in Ruefli, Salazar, and wilson $(1984)$ and will not be repeated here.

III. DATA

The usual approach to industry analysis is to use absolute levels of performance or ratios of those absolute levels. The approach here utilizes input data in the form of rankings of firm performance over time for each of the selected performance dimensions. If the data on firm performance are in cardinal form (i.e., absolute numerical levels of performance or their ratios) they must be transformed to yield ordinal rankings, that is, the firms must be ordered (e.g., sorted or indexed) each year aiong 
each dimension, and assigned ranks based on their performance. The data we will use here are the rankings developed by Eortune magazine for the transportation industry for the period 1957 to 1984. The particular dimensions of rankings examined here include operating revenue, net income, return on equity, assets, and number of employees. The latter rankings are available only from 1965 to 1984 .

As with any data, the Eortune rankings have some limitations that should be noted. Firms are included in the Eortune transportation file if they are publicly listed U.S. firms and if more than $50 \%$ of their operating revenues come from transportation-related activities. Rankings along the other dimensions selected for analysis: net income, assets, and return on equity are contingent on the firm being in the top 50 along the dimension of revenue. Thus there may be firms that have net income or other performance figures that would place them in the top fifty by that measure, but because their revenue figures are not high enough, they are not listed. Since firms are classified as being in an industry on the basis of their revenues, single product or service firms are lumped together with nearconglomerates. Also, since only the largest firms in the industry are ranked by fortune, that portion of industry activity attributable to the number of small, growing, and potentially important firms will not be incorporated directly into the analysis until those firms are in the top fifty firms. Thus this 
analysis is from the point of view of the incumbents in the industry and should be interpreted from that perspective.

Two conventions should be noted at the outset. By convention mergers of ranked transportation firms with firms outside the top fifty did not result in a new entity and were treated as a continuation of the previously-ranked firm for the purposes of the analysis. In the event of a merger between two previously ranked firms, the entities prior to the merger were considered to have been dropped from the rankings following the merger and the resulting entity was treated as a newly-ranked firm. Because firms leave and enter the top fifty from year to year and are not ranked when they are not in the top fifty a convention of assigning a rank of "51" to unranked firms was adopted. This was felt to be conservative with respect to the analysis insofar as the actual rank of firms outside the top fifty is, in all but at most one case, greater than 51 .

\section{INDUSTRY RESULTS}

In order to place the evaluation of the impacts of deregulation on the performance of the largest transportation companies in perspective, we will first analyze the rank shift behavior of the top fifty transportation firms as a group. We will then decompose this group into subgroups based on 
transportation modes and analyze the performance of selected whote subgroups. Following that we will focus on representative individual firms in the railroad and trucking subgroups and evaluate their performance in relation to the top fifty transportation firms. The analysis will conclude with an examination of selected airline companies relative to all top transportation firms.

\section{A. Transportation Firms}

Average rank position is a meaningless measure for the industry as a whole, since it ls a constant for each yeari rank shift volatility is, however a useful measure at this level. The increasing turbulence in the transportation industry in the past two and one-half decades can be clearly seen in figure 1, where the volatility cmeasured by the average absolute level of rank shifts from one year to the next) is graphed. From 1958

$* * * * * * * * * * * * * * * * * * * * * * * * * * * * * * * * * * * * * * * * * * * * * * * * * * * * * * * * * * *$ INSERT FIGURE 1 HERE

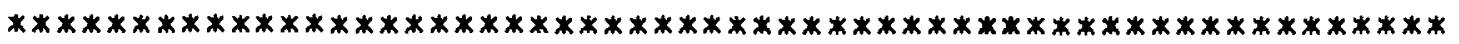
through the middle 1960's volatility levels were stable across all dimensions, with the average firm shifting one position or less on operating revenue and asset rankings, two positions on net income rankings, and four positions or less on return on equity rankings. In the later sixties, as the figure shows, 
volatility rose on all dimensions, peaking in 1969 with the economy-wide merger and acquisition wave and the reorganization of the eastern railroads. After a settling down period in the early $1970^{\circ} \mathrm{s}$, volatility levels began a general long-term increase that continues to the present. Recent volatility levels are double those of a quarter-century ago, with volatility in return on equity spiking to very high levels in 1981 and 1983 . This is a graphic depiction of the impacts of deregulation and increased economic uncertainty on the industry, and suggests that the management environment of the firms in the industry is likely to be significantly different than it was just a decade ago.

The top section of Table 1 shows the uncertainty associated with the rank shifts along the various dimensions of performance for the transportation industry. The levels reported are percentages of the level of uncertainty that would exist if rank changes were a totally random process. The results are not all as might be expected. Return on equity shifts are most uncertain, followed by net income shifts, operating revenue, and assets, $* * * * * * * * * * * * * * * * * * * * * * * * * * * * * * * * * * * * * * * * * * * * * * * * * * * * * * * * * * * *$

\section{INSERT TABLE 1 HERE}

************************************************************

with shifts based on the number of employees, somewhat surprisingly, being the most certain ci.e., least likely to occurj. The implication here is that the firms in the 
transportation industry tend to adjust their work-forces in a more consistent way than they adjust asset levels or market share.

We will now examine and contrast the behavior of four transportation industry subgroups, railroads, airlines, trucking, and plpelines in the context of the general increasing instability of the top transportation firms.

B. Railroads

The contribution of the top railroad firms to the volatility of the top transportation firms can be assessed from figure 2 . Herein it can be seen that the railroads were major contributors

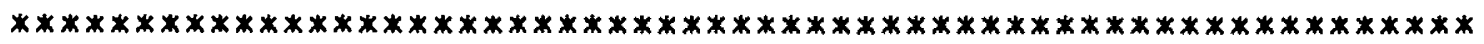
INSERT FIGURE 2 HERE

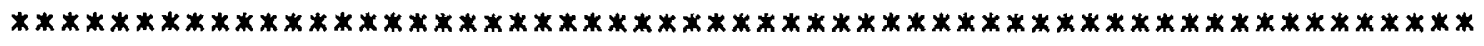
to the spike in rank shift activity in 1969 and to return on equity activity in 1981 and 1983, but, other than that, were not as volatile in their activity as was the average transportation firm. In the post-1970 period the activity levels of the various dimensions move more in concert with each other, with a rising trend in the last decade.

Before examining the average rank position of the railroads, a word about interpreting the position graphs is in order. The 
firm with the largest actual performance measure is given the rank of one, the highest rank; the firm with the next largest value of the actual performance measure is given the rank of two, etc. The highest ranks appear at the bottom of the position graphs - a convention enforced by the graphics package used. So the lower the physical position on the graph, the higher the ranking.

As Figure 3 shows, the performance of the largest railroads, relative to other large transportation firms, has worsened over the period of the study. The worsening has occurred on all dimensions, al though not uniformly. Asset, employee, and operating revenue position have worsened in almost every year. Net income and return on equity positions improved in the reorganization period just before 1970, and both held steady or improved slightly during the energy crisis. Return on equity has

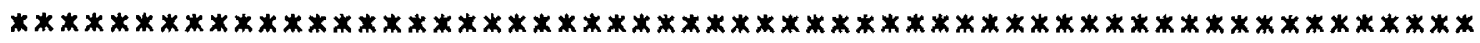
INSERT FIGURE 3 HERE

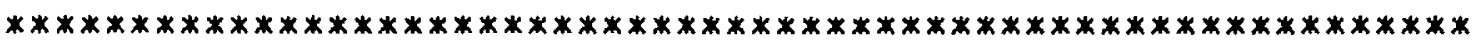
had the worst position in all but two years and exhibits a much more pronounce cyclic pattern than do the other dimensions. The other two improvement periods in return on equity position in 1960-61 and 1979-81 followed legislation aimed at helping the railroads. 
Measurement of productivity of labor in the transportation has been a major methodological problem [Lieb (1981), p. 279 ]. The methodology used here provides a ready indication of relative productivity. The relation of rank by number of employees relative to the rankings on other dimensions gives an indication of the relative productivity of labor. For example, ranking by number of employees that is higher in rank than that of operating revenue, as is the case for railroads, Indicates a relatively poor average sales per employee in comparison to other firms in the rankings. The higher average rank position of number of employees when compared to net income also indicates a relatively adverse profit per employee.

The rank data also show that the energy crisis in the early $1970^{\prime}$ s had little impact on the rallroads relative to other transportation firms. As Figure 3 shows, there is no significant shift in average rank position in the perlod of the sharp increases in the price of oil. This means that railroads were no more or less sensitive to price increases or shortages of fuel supply than other transportation modes - given the government allocation programs in place at the time.

Returning to Table 1 we can note that the railroads followed the pattern of the transportation industry as a whole in terms of the uncertainty of the rank shifts in the period 1957 to 1984 . 
C. Airlines

The top airline firms show a substantially different pattern of rank shift activity than did the rallroads or the the top transportation firms as a whole. Airlines make only a modest contribution to the spike in rank shift activity in all transportations in 1969 (see Figure 1), but do have a sizable spike of their own on the dimenslons of net income and return on equity in 1970 (Figure 4). This was a result of adverse airline industry conditions in that period cas indicated by the only

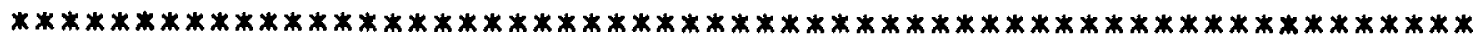

\section{INSERT FIGURE 4 HERE}

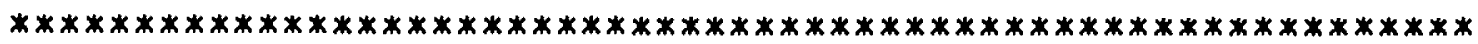

nominal increase in operating revenue and asset rank shift activity) rather than a result of merger and acquisition or reorganization (which would have generated shifts in all dimensions). Notice that operating revenue and asset rank shifts remain at a consistently low level until 1977. As deregulation occurs, rank shifts on these two dimensions begin to increase sharply, quadrupling by 1982 and improving somewhat in the last two periods. At the same time net income and return on equity activity continue their cyclic pattern around an increasing trend line originating in 1964 . 
The average rank position of the airline companies has steadily improved in the period 1957 to 1982 , as Figure 5 shows. Improvement has been relatively uniform on operating revenue $* * * * * * * * * * * * * * * * * * * * * * * * * * * * * * * * * * * * * * * * * * * * * * * * * * * * * * * * * * * * *$

\section{INSERT FIGURE 5 HERE}

\section{$* * * * * * * * * * * * * * * * * * * * * * * * * * * * * * * * * * * * * * * * * * * * * * * * * * * * * * * * * * *$}

and asset dimensions, with net income and return on equity following the cyclic pattern in the post-1964 perlod as noted above. The effects of the rate freeze from 1962 to 1968 can be seen clearly in the ordinal data. For the first four years of the freeze, the average return on equity dramatically improves position and then worsens somewhat in the iast three years of the perlod. Net income position, on the other hand, improves in position in all but the last year of the freeze. The net effect of the freeze was to leave the airlines in a relatively better position than before. With the rates unfrozen in 1968 the airline return on equity and net income positions returned to their improving trend until 1972. The last cycle on these two dimenslons peaked in 1982, followed by two years of relative improvement.

In contrast to the railroads, the levels of uncertainty associated with rank shifts on the various performance dimensions (Table 1) do not follow the industry pattern. Return on equity and net income are the two most uncertain measures, both at levels well above the industry average. However asset shifts are 
next in uncertainty, followed by employee rank shifts. For the al rlines, rank shifts on operating revenue performance are the most certain, indicating that airlines are relatively stable with respect to market share. This implies that airlines have more of a market share strategy emphasis in their corporatedecisionmaking than do the other transportation modes. According to the data presented here, airline managers, in comparison with managers of other transportation firms have accepted wider swings In relative levels of net income, return on equity, assets, and even levels of their work-forces in order to stabilize market share. Recent higher levels of market share stability indicate that the focus on this strategic dimension has increased as deregulation has taken effect.

In a small divergence from the sltuation with the railroads, the airlines as a group show some effects of the energy crisis relative to other transportation firms. Figure 5 shows a relatively smooth transition in rank position through the period of oil price increases for operating revenue and assets, but the worsening of the net income and return on equity positions from 1972 to 1976 can, in part, be attributed to rising fuel prices. This indicates that airlines were relatively more sensitive to fuel prices than were the railroads. This is not unexpected since airlines have low fuel efficiencies when compared to other transportation modes [Lieb $(1981), p .336]$. 
it is also interesting to compare the relative position of average rank by number of employees for the airlines and railroads. Note that in Figure 5, with the exception of the last year, average employee rank for the airlines is worse than average revenue rank. The interpretation of this is that airlines have had favorable empioyee productivity in terms of revenue generate when compared to other transportation firms. The data indicate that this advantage has moved to a parity position in 1978 (when average revenue rank equaled average employee rank) and was reversed in 1984.

D. Trucking

The pattern of volatility of rank shifts in the trucking subgroup is shown in Figure 6. In the first decade studied $* * * * * * * * * * * * * * * * * * * * * * * * * * * * * * * * * * * * * * * * * * * * * * * * * * * * * * * * * * *$

\section{INSERT FIGURE 6 HERE}

$* * * * * * * * * * * * * * * * * * * * * * * * * * * * * * * * * * * * * * * * * * * * * * * * * * * * * * * * * * *$ operating revenue, asset, and net income shifts are low and comparable, only return on equity shows moderate levels of volatility. This was, of course, a period of substantial regulation in the trucking industry. Beginning in 1967 volatility on all dimensions increases with return on equity and net income volatility doing so sharply. This increase peaks in 1975 and is a major contributor to the peak in transportation volatility in that period. After a brief lull in 1976 the aggregate rank shift 
activity on all dimensions resumes its upward trend. Notice that return on equity and net income volatilities move together and, to an even greater degree, so do operating revenue and asset volatilities.

Figure 7 shows that the average rank position of the trucking group shows improvement on all dimensions until

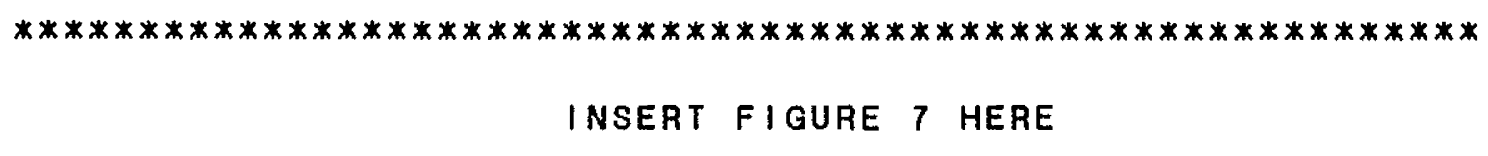

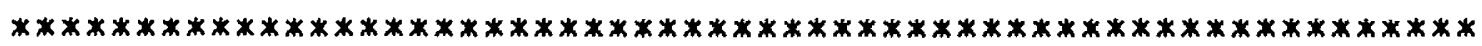

1971, with return on equity position leading the way. The onset of the energy crisis reversed the improving trend in net income and return on equity, and even adversely affected average operating revenue position in 1973 and 1974. Even though return on equity position deteriorated from 1972 to 1982 , it was still far below the average revenue position, indicating favorable performance on this dimension relative to other transportation firms. Relative employee productivity has not fared so well, as shown by the high employee rank position. Deregulation, potential and actual (in 1980), of this subgroup lead to a stabilizing of the revenue and asset rank positions and was followed by improvements in financial performance rankings. 


\title{
E. Pipelines
}

\begin{abstract}
Perhaps the clearest case of deregulation having a differential effect on a group of transportation companies is that of the pipelines. The horizontal line at rank 51 from 1957 to 1978 in Figure 8 means that in that period pipelines were not ranked $* * * * * * * * * * * * * * * * * * * * * * * * * * * * * * * * * * * * * * * * * * * * * * * * * * * * * * * * * * * * *$

\section{INSERT FIGURE 8 HERE}

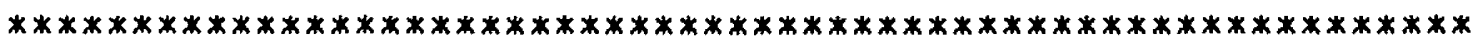

in the top fifty transportation firms. When the Natural Gas Regulatory Act of 1978 deregulated the pipelines, they quickly took entrepreneurlal advantage of the opportunity to expand and combine. As a result, the largest of them on average jumped from out of the rankings in one year to the the mid-point in the rankings the next year.

Their low average ranking by number of employees, compared to average rankings on all other dimensions shows substantial relative employee productivity, as might be expected in a capital-intensive business. This latter situation is indicated by the relatively high average ranking based on assets. Return on equity rankings performed spectacularly in the first three years after deregulation and, like net income position, began to gradually worsen. 
F. Comparison and Implications

The key dereguiatory events in the transportation industry were 1) the Natural Gas Dereguiatory Act of 1976, 2) the Railroad Revitalization and Regulatory Reform Act of 1976 3) the Airline Deregulation Act of 1978, an 4) the Motor Carrier Act of 1980. CThe effects of the end of CAB controls over airline rates in 1983 are too recent to be evaluated.) While the shift in the rank performance of the pipelines in the rankings can be traced directly to deregulation in 1976, the shift in the relative fortunes of the rallioads on one hand and the airlines and trucking on the other is, over the period studied, of course, due to more than the effects of deregulation. The rapid improvement in airline technology relative to railroads, the shift in travel patterns, the near-completion of the federal interstate highway system, and the increase in the relative production of high value to weight products on the part of the rest of the industrial sector, have played major roles in the performance shifts noted here. The clear effects of deregulation in these subgroups can best be seen in the last years of the period studied here in the uncertainty imposed on the trends generated by the aforementioned external forces. That is, without deregulatory acts the trends of airline and trucking improvement and railroad worsening in performance would be expected to continue. In this period there is no indication that the rate of technological change increased, but the levels of rank shift and the associated 
uncertainties increase substantially. These latter show the clear effects of the turbulence brought about by deregulation. Thus, for these three groups, the effects of deregulation as revealed by the methodology employed here do not so much affect the relative positions of the sub-groups as a whole, but do affect industry volatility and within-group positions of individual firms. That this is the caso will be seen more clearly in the ensuing analysis.

V. ANALYSIS OF INDIVIDUAL FIRMS

Having established Industry and subgroup patterns of behavior during the period of deregulation, it is now possible to use the rank analysis methodology to analyze individual firms on a comparative basis to examine firm-level responses to deregulation. The transformation to ordinal data also suppresses short-term noise in firm behavior. The comparison at the firm level can be made to both the industry level and the sub-industry level, with strategic elements being ldentified in both contexts. We turn now to an examination of the rank performance of two railroad companies, three trucking firms, and five individual airlines. These firms will be examined in the context of their performance relative to all other large transportation companies. 
A. Railroads

Two dominant patterns emerge in the analysis of individual railroad firm rank behavior. The most-followed strategy in this industry over the past quarter century was to stay predominantly in the railroad business and grow horizontally by absorbing other firms, or to be absorbed. A second strategy was to keep the railroad business as a base, but to diversify into other businesses. The two railroad companies analyzed below are representative of these two strategies.

1. Chicago-Milwauke Rail road

of the two dominant patterns exhibited by railroad companies over the past quarter century, the Chicago-Milwaukee pattern of rank behavior exemplifies the firm that stayed largely in the railroad business. As Figure 9 demonstrates, return on equity $* * * * * * * * * * * * * * * * * * * * * * * * * * * * * * * * * * * * * * * * * * * * * * * * * * * * * * * * * * *$ INSERT FIGURE 9 HERE

$* * * * * * * * * * * * * * * * * * * * * * * * * * * * * * * * * * * * * * * * * * * * * * * * * * * * * * * * * * *$

position leads the pattern of worsening rank positions. Operating revenue shows a relatively steady decline in rank position, with rapid worsening in the period from 1976 to 1980 , when it levels off. Both asset and employee positions lie below the other rank positions, indicating relatively poor productivity on both human 
factors and capital. Net income position follows return on equity and drops from the rankings in 1978 .

\section{Southern Pacific Railroad}

The second dominant rank pattern exhibited by railroad companies in the period studied is illustrated by southern Paclfic's rank positions (Figure 10). Southern Pacific, like ************************************************************** INSERT FIGURE 10 HERE

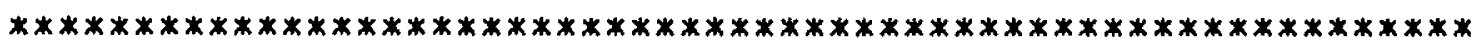
Santa Fe Industries, Rio Grande Industries and others, diversified away from the railroad business, but, of course, still derived better than fifty percent of lts operating revenue from transportation. For southern pacific and those like it. return on equity rank is by itself, worsening over the period in a cyclic fashion, and more poorly positioned than the ranks on all other dimensions. All other dimensions are comparably ranked until a gradual divergence and slight worsening in position takes place in the last twelve to fifteen years. The merger in 1983 dropped southern pacific as an individual entity from the rankings. 
8. Trucking

Analysis of the rank behavior of the trucking industry yielded no strategy groupings similar to those found in the railroad industry. A pattern did, however, emerge in that

successful trucking firms were found to have brought, or to be in the process of bringing their rank positions on the various dimensions measured into agreement. That is, if a successful trucking firm was in the th $^{\text {th }}$ position in terms of revenue in 1984, its ranks on the other dimensions (with the exception of assets, which were always lower rankedl were likely to be near the $i^{\text {th }}$ position also. Since the firms in the top fifty are there because of their operating revenue size, the interpretation of this behavior is that the managers of these firms responded to the uncertainty in their environment by reducing their strategic options and the scope of their firm's activities to be proportional to their revenue position. This implies that the firmestablished a balanced position cvis a vis other large transportation firms that would allow management to better copo with the environmental and industry uncertainty. The three firms selectedall exhibit this behavior at some time in the period examined. Consolidated Freightways and Roadway Express were selected because they represent main-stream trucking firms, while United parcel service was included to show the effects of being in a high-growth segment of trucking. 
1. Consolidated Freightways

Consolidated Freightways improvement in rank performance (Figure 11) exceeds the industry as a whole on all dimensions except return on equity in six years and net income in one year. This firm shows the high asset productivity associated with trucking and, except for poor returns in 1960 and 1961 , the return on equity position is excelient until 1972. The energy $* * * * * * * * * * * * * * * * * * * * * * * * * * * * * * * * * * * * * * * * * * * * * * * * * * * * * * * * * * *$ INSERT FIGURE 11 HERE

**************************************************************

crisis forced a weakening in return on equity and net income ranks for two years, but both recovered somewhat in 1974 .

Operating revenue for Consolidated improves rather steadily unti 1980 when it declines in rank for one year and then resumes its trend. While not experiencing any great relative employee productivity, Consolidated keepsemployee position in line with revenue position. The deregulatory year of 1980 saw a worsening of return on equity and net income positions. The latter ranking was brought into line the next year, but for the former two very bad years followed. The years since deregulation have seen management improve return on equity and bring net income, operating revenue and number of employees into near-identical positions, as was mentioned above. 
2. Roadway Express

Roadway Express appeared in the top fifty revenue rankings in 1960, as shown in Figure 12. The outstanding return on equity position of this firm in its first four years in the rankings is evident. However, since 1963 this position has gradually eroded. $* * * * * * * * * * * * * * * * * * * * * * * * * * * * * * * * * * * * * * * * * * * * * * * * * * * * * * * * * * * * *$ INSERT FIGURE 12 HERE

$* * * * * * * * * * * * * * * * * * * * * * * * * * * * * * * * * * * * * * * * * * * * * * * * * * * * * * * * * * * *$

The pattern of rank behavior is much smoother for Roadway than it was for Consolidated (Figure 11). Only a slight worsening in all but asset position is shown during the energy shortage. Roadway's management brought rank position on all dimensions except assets into alignment through the 1970's. When deregulation legislation was passed in 1980, the firm was in good position and good shape to take advantage of the situation.

\section{United Parcel Service}

Consolidated Freightways and Roadway Express are in relatively the same segment of the transportation business. United Parcel Service participates in a different strategic group and its rank performance (figure 13) is consequently quite different. Out of $* * * * * * * * * * * * * * * * * * * * * * * * * * * * * * * * * * * * * * * * * * * * * * * * * * * * * * * * * * * * *$ INSERT FIGURE 13 HERE 
the top fifty transportation firms until 1975, UPS entered at the eighth position in terms of operating revenue and in the first position in terms of number of employees. While the revenue position has improved over the last decade of the study, the rank by number of employees continues to show the labor-intensive strategy of UPS. The uncertainty caused by deregulation does not show up in the rank positions of UPS. The growth of its segment of the business has been sufficient to swamp noise caused by uncertainty, and UPS has managed this growth well - at least in terms of its rank positions. The nearly-identical rank positions of revenue, net income, and return on equity in the last two years coupled with the very high employee rank position, indicate a well-balanced, mature firm with a service strategy.

C. Airlines

In the previous two section we have examined selected railroad and trucking firms in terms of their performance relative to the other top fifty transportation firms. In this section we will examine five airline firms on that basis. The five airlines analyzed, United, Northwest, Delta, American and Pan American were chosen because of the differing characteristics of their rank performance and the effects of impending and actual deregulation on that performance. 
1. United Airlines

Figure 14 shows, for example, that in relation to the

\begin{abstract}
$* * * * * * * * * * * * * * * * * * * * * * * * * * * * * * * * * * * * * * * * * * * * * * * * * * * * * * * * * *$
FIGURE 14 HERE
\end{abstract}

$* * * * * * * * * * * * * * * * * * * * * * * * * * * * * * * * * * * * * * * * * * * * * * * * * * * * * * * * * *$

top fifty transportation firms, United Airlines has been a leader in the airline subgroup's Improvement in operating revenue and asset rankings, and that United follows the subgroup pattern of stabilizing these two performance dimensions in the period after 1969. Unlike the other two airlines analyzed here, United engaged in acquisitions outside the airline industry, to the point where $90 \%$ of it's revenues were non-airline in 1982. In the period from 1957 to 1969 United had moderate fluctuations in return on equity and net income. Beginning in 1970, when western International Hotels were acquired concurrently with loss of key Hawai ian routes (Byrnes $1985, p .38$ ) United experienced wide fluctuations in return on equity and net income. The second large adverse shift in these two measures coincides with the acquisition of GAB in 1975. An improvement in both measures coincided with a change in the investment tax credit laws in 1977 (Byrnes 1985, p. 87) The third major worsening coincided with the formal implementation of deregulation in 1978. Byrnes (1985, p. 122) states that united was one of the airlines that saw its prospects improve with deregulation. In fact, according to the methodology 
employed here, United's performance did not begin to improve until 1982, and did not approach pre-1969 levels of net income performance until 1984. Even then, return on equity position was still poor.

2. Northwest Airlines

Northwest Airlines, on the other hand, as shown in Figure 15, has made greater gains in asset and revenue rankings relative $* * * * * * * * * * * * * * * * * * * * * * * * * * * * * * * * * * * * * * * * * * * * * * * * * * * * * * * * * * * *$ INSERT FIGURE 15 HERE

***********************************************************

to the top transportation firms, and in the period from 1969 to 1979 brought those two rankings to near equality. In the last five years of the study, revenue position has improved relative to asset position, signaling improved relative use of assets on the part of Northwest's management. In the period up to 1970 , Northwest had an excellent return on equity position and until the last few years of the data has enjoyed better net income and return on equity rankings and lower fluctuations in those rankings than had United Airlines. Relative to the transportation industry, Northwest shows good relative employee productivity as its average rank on this dimension is worse than its revenue position in all periods where there is data for both. 
To highlight the different view that our methodology provides consider statements made by Byrnes (1985) about Northwest based on cardinal data analysis: "a profitable, slowgrowth strategy such as Northwest's."(p.45) and "Delta and Northwest prospered throughout most of the dereguiatory transition period." (p. 68). In fact, Figure 15 shows that between 1964 and 1974 Northwest had no relative growth in the period, and worsening profitability from 1969 to 1984 . The ability of the analysis based on rank positions to eliminate short-term noise from business cycles and inflation, and show just those effects that are differential, yields a view that suggests a different Interpretation, than provided by standard analysis.

3. Delta Airlines

Figure 16 shows that, like Northwest, Delta Airlines experienced steady improvement relative to other transportation firms on most ranked dimensions from 1957 to 1976 . Asset and employee positions prior to 1975 indicate relative high $* * * * * * * * * * * * * * * * * * * * * * * * * * * * * * * * * * * * * * * * * * * * * * * * * * * * * * * * * * *$ INSERT FIGURE 16 HERE

$* \star * * * * * * * * * * * * * * * * * * * * * * * * * * * * * * * * * * * * * * * * * * * * * * * * * * * * * * * * * *$ productivity of these factors. Return on equity position is excellent until 1975 and net income position is favorable until 1979, but as deregulation takes effect and the industry becomes 
more turbulent, return on equity and net income positions worsen for several years and improve only in the last year examined. The quotation from Byrnes cited just above concerning Delta's "prosperity" during deregulation is contradiced by this pattern. The essential point here is that Delta was positioned in terms of Its rank positions being alligned in the late seventies so that even though profitability fell as deregulation went into effect, the airline was able to quickly recover by 1984.

\section{American Airlines}

At the outset of the period studied here. American Airlines already had a well-established position in the transportation Industry (Figure 17). Except for a substantial worsening in return on equity and net income positions in the early sixties, $* * * * * * * * * * * * * * * * * * * * * * * * * * * * * * * * * * * * * * * * * * * * * * * * * * * * * * * * * * * * *$ INSERT FIGURE 17 HERE

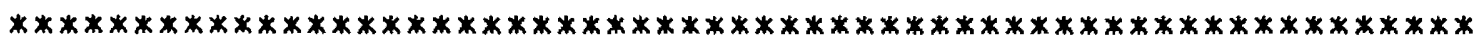
those positions improved until 1969. In the period 1969-1976, American embarked on a series of diversification moves that are graphically reflected in the poor return on equity and net income positions in those years. Improvement in these positions is not seen until American reduced its diversification in the last part of the seventies. The other three dimensions of performance improve slightly or remain the same until, at the end of the period, they are generally in agreement in terms of their rank 
position, Indicating that management responded to the uncertainty of deregulation by balancing market pertormance and resource utilization. With the onset of deregulation American's return on equity and net income positions, which had improved markedly, worsened in the post-deregulation period cas was the case for the preceding airlines examined) but was brought back in 1983 and 1984.

To show how information gained through rank analysis complements traditional analysis, consider Byrnes statement $(1985, p .90)$ that "American's earnings variance was very similar to, or lower than those of the four nondiversifying firms, yet American diversified actively. In the period immediately preceding American's major entry into the hotel business, it ranked second in earnings stability. In the following periods, spanning 1969 to 1978, it had only moderate variance, but it substantially increased its diversification. Therefore, earnings variance does not seem to have been an important motivation for American's diversification." Figure 17 indicates that in the pre-1969 period American did have low variance on return on equity position, but at worse (and worsening) rank positions than airlines such as Delta and Northwest (Figures 15 and 16). In the post-1970 period, American did have moderate variance in ROE, but at much worse (but improving) rankings than the nondiversifying airlines. Thus Byrnes is correct as far as he goes; the rest of the story is that worsening earnings position probably was an important 
motivating factor for diversification and desire for improvement In that position and net income position probably fueled further diversification.

\section{Pan American}

The rank positions of Pan American over time in relation to the top fifty transportation companies (Figure 18) provides a graphic illustration of the impacts of deregulation and management's reaction. Up until 1969 Pan American was making rank position gains on all dimensions. When the Civil Aeronautics Board made the transpacific awards in that year and Pan American diversified, the impacts on return on equity and net income

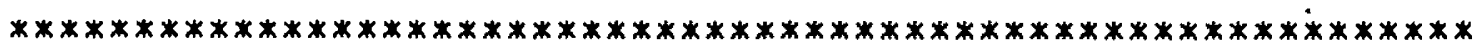
INSERT FIGURE 18 HERE

*************************************************************** positions were immediate and disastrous as the graph shows. (In contrast, Byrnes (1985, p. 50), referring to absolute levels of returns, reports "Pan American's diversification raised its returns, which benefited both society and the airline." J The operating revenue, asset, and employee positions began to slowly erode, to be reversed only slightly and temporarily in 1980 with the purchase of National Airlines. The other two performance dimensions did not improve until the company made a substantial sale of assets in 1976, but the effect was only temporary. The 
purchase of National accelerated the decline in net income rank, to be followed by similar behavior in return on equity rank.

\section{Implications}

As was hypothesized at the conclusion of the last section of this paper, analysis of individual firms in the railroad. trucking and airline industries reveals that deregulation, while not altering the change in relative positions of the various modes of transportation (with the exception of pipelines), does alter the positions of individual firms within the mode groups. The analysis showed strikingly different patterns of response to the changing conditions in the transportation industry over the past quarter-century.

In the airline industry, attempts at diversification in the late sixties and early seventies to buffer the possible effects of Impending deregulation lead those airlines following this strategy to destabilize their relative profitability. When deregulation became a fact in the lateseventios, allairlines, regardless of the strategy adopted, had their profitability destabilized. The rank data presented here implies that the managerial response to deregulation in this industry was to attempt to maintain market share and asset rank stability. The evidence further indicates that stability in market share and 
evidence further indicates that stability in market share and assets was paid for by instability in return on equity and net income positions. Fecent data imply that while instability of this typestill exists in this industry, some firms are bringing their performance into a balanced position and have prepared to cope in the new environment.

This last-mentioned situation is also the case for the firms In the trucking industry. Deregulation has affected the relative profitability of a number of firms, but those in fast-growing market niches, e.g. United Parcel Service, and those who have balanced their performance, e.g., Roadway, have been able to maintain their relative profitability. In the railroad industry, on the other hand, if deregulation had any effects, they are not noticeable in the analys is presented here. Individual railroad companies continue thelr relative decline in performance on al dimensions in a comparatively smooth fashion. Apparently the maturity of the sub-industry mitigates against differential effects due to deregulation, and even strateglc differences such as diversification or non-diversification do not appear to have a substantial effect. 
VI. CONCLUSIONS

In this paper we have presented an analysis of the impacts of deregulation on the transportation industry In general and the railroad, trucking, and airline industries in particular from a new perspective. We have examined the situation in the transportation industry in a highly relativistic fashion by using the rank position data of the firms in the industry. The multiple perspectives generated here have revealed that the primary impact of deregulation at the industry level has altered the pattern of change among the major transportation modes only in the case of pipelines, but has not affected the relations among rallroads, airlines, and trucking modes in a similar fashion. The major impact of deregulation for these three modal groups was to raise the levels of volatility and uncertainty within the groups. Thus, Impacts of deregulation show most clearly in the differential behavior of Individual firms as opposed to groups of firms. Analysis of individual railroads showed similar results for different diversification strategies. Analysis of individual airlines indicated that profitability was hurt both by diversification and by deregulation, and analysis of trucking firms showed that growth strategies couid swamp the effects of deregulation. 
Two interesting patterns that have been noted, but not fully explained here, are: 1-declines in return on equity position tend to lead the decline on all other dimensions for groups of firms, and 2- the better managed firms tend in times of environmental turbulence to bring the performance rankings on all dimensions into agreement, conditioned on the capital intensity of the industry sub-group. Further study is required to ascertain if the observed relationships can be generalized, perhaps to the point that they can be used for managerial analysis and/or prediction. 
Acknowledgments

The author would like to acknowledge the helpful suggestions given by Richard Burton and Borge Obel and the support provided by the $1 c^{2}$ Institute and Project OUEST of the University of Texas at Austin. 


\section{BIBL I OGRAPHY}

[1] Altshuler, Alan, Current lssues in Transoortation Policy, Lexington Books, Heath \& Co., Lexington, Mass., 1979. .

[2] Ansoff, Igor, Coroorate Strategy, McGraw-Hill, Now York, 1965 . .

[3] Boisjoly, Russel P., and Thomas M. Corsi, "The Aftermath of the Motor Carrier Act of 1980: Entry, Exit, and Merger," Proceedings of the 23 id Annual Meoting of the Iranseertation Besearch Forum, pp. 258-264, 1982 .

[4] Byrnes, Jonathan L.S., Diversification Strategies for Begulated and Deregulated Lodustries: Lessons from the Alrlines, Lexington Books, Lexington, Mass., 1985. .

[5] Caves, Richard E., American Industry: Structure, Cenduct, Performance, Prentice-Hall, Englewood Cliffs, N.J., 1964. .

[6] Caves, Douglas W., Laurlts R. Christiansen, and Michael W. Trethway, "U.S. Trunk Air Carriers, 1972-1977: A Multilateral Comparison of Total Factor Productivity," in Productivity Measurement in Requlated Industries, Cowing, Thomas G., and Rodney E. Stevenson (ed), Academic Press 1981 . .

(7) Cunningham, L.F., and W.R. Wood, "Diversification in Major U.S. Airlines," Iransoortation Jeurnal, Spring 1984.

[8] Diewert, W. Erwin, "The Theory of Total Factor Productivity Measurement in Regulated Industries." in Productivity Measurement in Reguelated Industries. Thomas $G$. Cowing and Rodney E. Stevenson (ed), Academic Press, 1981.

(9) Eortune, Time, Inc. 1954-1985.

[10] Friedlaender, Ann F., and Richard H. Spady, Ereight Iransoort Regulatien. The MIT Press, Cambridge, Mass., 1981. 
[11] Fruhan, W. The Fight for Competitive Advantage: A Study of the United States Domestic Trunk Air Carriers, Division

of Research, Harvard University, Boston, Mass., 1972.

(12) Hax, Arnoldo, and Nicholas S. Majluf, Strategic Management: An lntegrated Perspective, Prentice-Hall. Englewood Cliffs, N.J., 1984.

[13] Hunsaker, James Kirk, "The Changing Shape of America's Airline Industry: An Analysis of the Deregulation strategles of Five Airlines," Proceedings of the 22nd Annual Meeting of the Transportation Research Forum, pp. 449-456, 1981.

[14] Kimberly, J.R., "Issues in the Design of Longitudinal Organizational Research," Soclological Methods and Research, Vol. 4, pp. 321-347, 1976.

[15] Kimberly, J.R., "Data Aggregation In Organizational Research: The Temporal Dimension, "Organizational studies, Vol. 1, Pp. 367-377, 1980 .

(16) Lieb, Robert C., Iransoortation: The Domestic System, 2nd edition, Reston Publishing, Reston, Va., 1981.

[17] Mandell, Robert W. Financina Capita! Requirements of the U. S. Airline Industry in the 1980s, Lexington Books, Heath \& Co., Lexington, Mass., 1979.

[18] Meyer, J.R. and C.V. Oster (ed), Airline Deregulation: The Esrly Experience, Aburn House, Boston, 1981 .

[19] Miller, D.., and P.H. Friesen, "The Longitudinal Analysis of Organizations," Management Science, Vol. 28 , No. 9, pp. $1013-1034,1982$.

[20] Morash, Edward A., and Charles Enis, "The Effects of Motor Carrier Deregulation: A Stock Market Perspective," Procedings of the 23rd Annual Meeting of the Iransportation Besearch forum, pp. 256-271, 1982 . 
(21) Office of Transportation Planning, Natienal

Iransportation. Irands and choices (to the year 2000), U. S. Department of Transportation 1978 .

[22] Porter, Michael E., Competitive Strategy, Free Press, New York, 1980.

[23] Ruefli, Timothy W., and Chester L. Wilson, "Comparative Relative Rank Methodology for Industry and Competitive Analysis," GSB-UT Working Paper 84/85-4-17, 1985.

[24] Salazar, Ronald, and Timothy W. Ruefli, "Concordance Measures for Industry Analysis," lC2 Working Paper, 1985.

[25] Scherer, F.M., Industrial Market structure and Economic Performance, Rand-McNally, Chlcago, 1980.

[26] Spady, Richard H., Econometric Estimation of Cost Eunctions for the Regulated Transportation Industries, Garland Publishing, New York, 1979.

(27) Steiner, George, Strategic Planning, Free Press, New York, 1979 .

[28] Taneja, Nawal K., The U. S. Alrtreight Industry, Lexington Books, Heath \& Co.., Lexington, Mass., 1979.

[29] Taneja, Nawal K., U. S. International Aviation Policy, Lexington Bookis, Heath \& Co.., Lexington, Mass., 1980.

[30], Temple, Barker, \& Sloane, Inc.. in Iransportation Strategies for the Eighties, National Council of Physical Distribution Management, Oak Brook, IL, 1982.

[31] Wycoff, D.D., and D.H. Maister, The Domestic Airline Lndustry, Lexington Books, D.C. Heath \& Co.. Lexington, Mass., 1977. 


$$
\begin{aligned}
& \text { PERCENT OF TOTAL POSSIBLE } \\
& \text { UNCERTAINTY BY PERFORMANCE DIMENSION }
\end{aligned}
$$

\begin{tabular}{|c|c|c|c|c|c|}
\hline & $\begin{array}{l}\text { OP REV } \\
\text { (1) }\end{array}$ & $\begin{array}{l}\text { NET IN } \\
(1)\end{array}$ & $\begin{array}{r}\text { EMPL } \\
(2)\end{array}$ & $\begin{array}{l}\text { ROE } \\
(1)\end{array}$ & $\begin{array}{l}\text { ASSETS } \\
(1)\end{array}$ \\
\hline $\begin{array}{l}\text { TRANSPORTATION INDUSTRY } \\
\text { TOTAL UNCERTAINTY ....... }\end{array}$ & $47.4 \%$ & $62.6 \%$ & $42.4 \%$ & $66.0 \%$ & $45.6 \%$ \\
\hline $\begin{array}{l}\text { RAILROAD SUB-GROUP } \\
\text { TOTAL UNCERTAINTY... }\end{array}$ & $47.0 \%$ & $62.3 \%$ & $43.4 \%$ & $70.8 \%$ & $44.2 \%$ \\
\hline $\begin{array}{l}\text { AIRLINE SUB-GROUP } \\
\text { TOTAL UNCERTAINTY.. }\end{array}$ & $28.9 \%$ & $71.8 \%$ & $30.0 \%$ & $79.6 \%$ & $39.8 \%$ \\
\hline
\end{tabular}
1) 1957-82
2) 1965-82

TABLE 1 


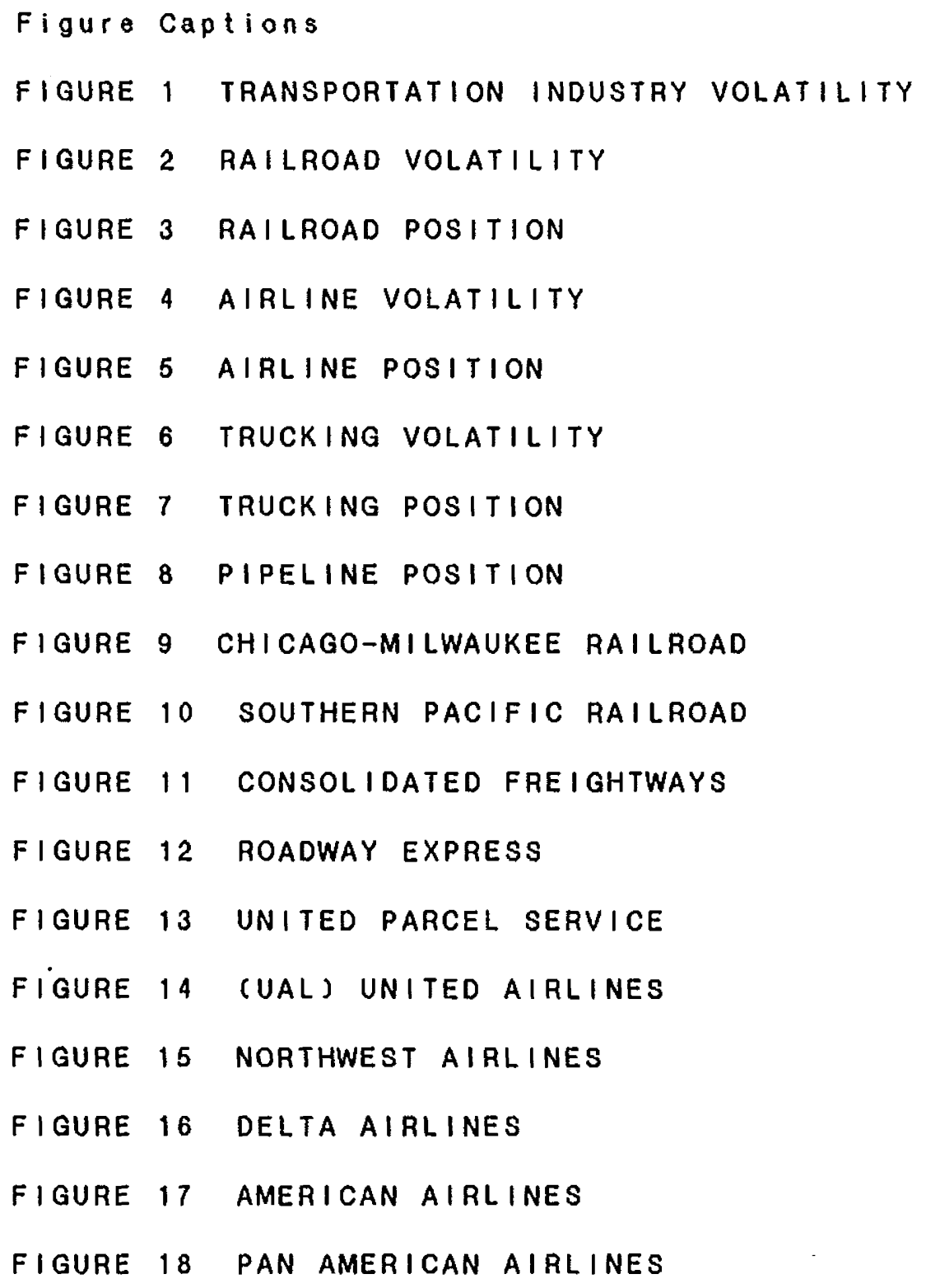




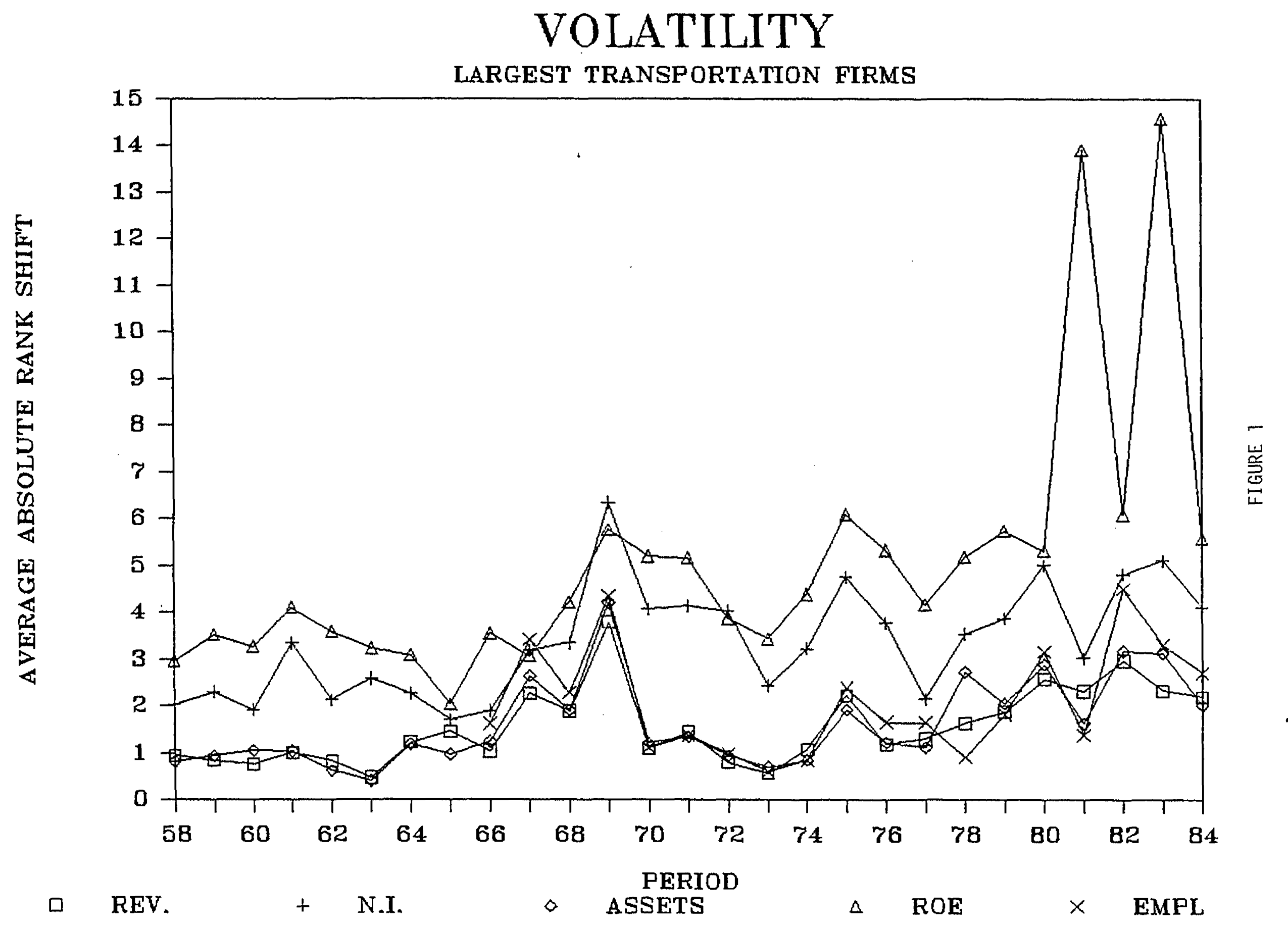




\section{VOLATILITY}

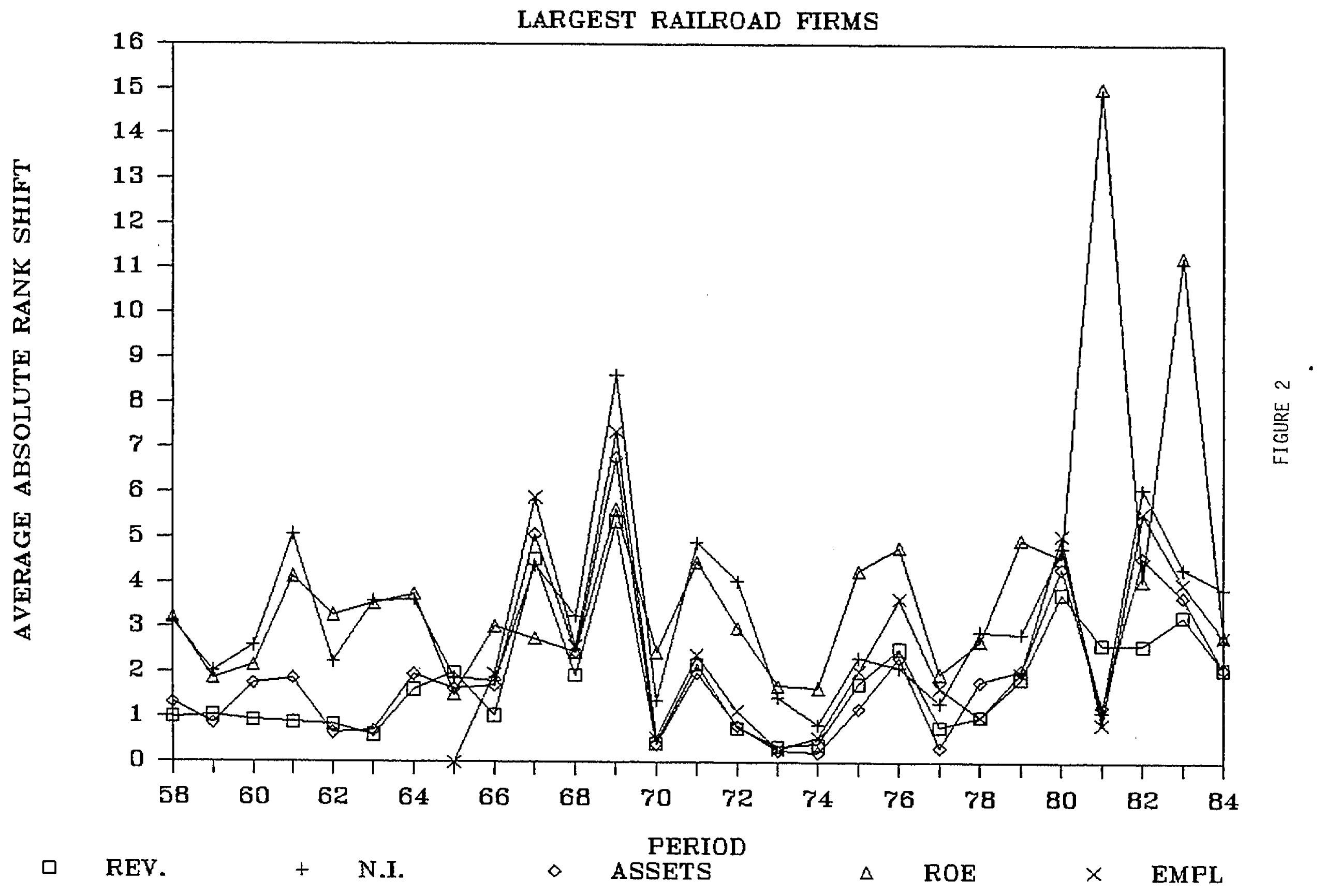




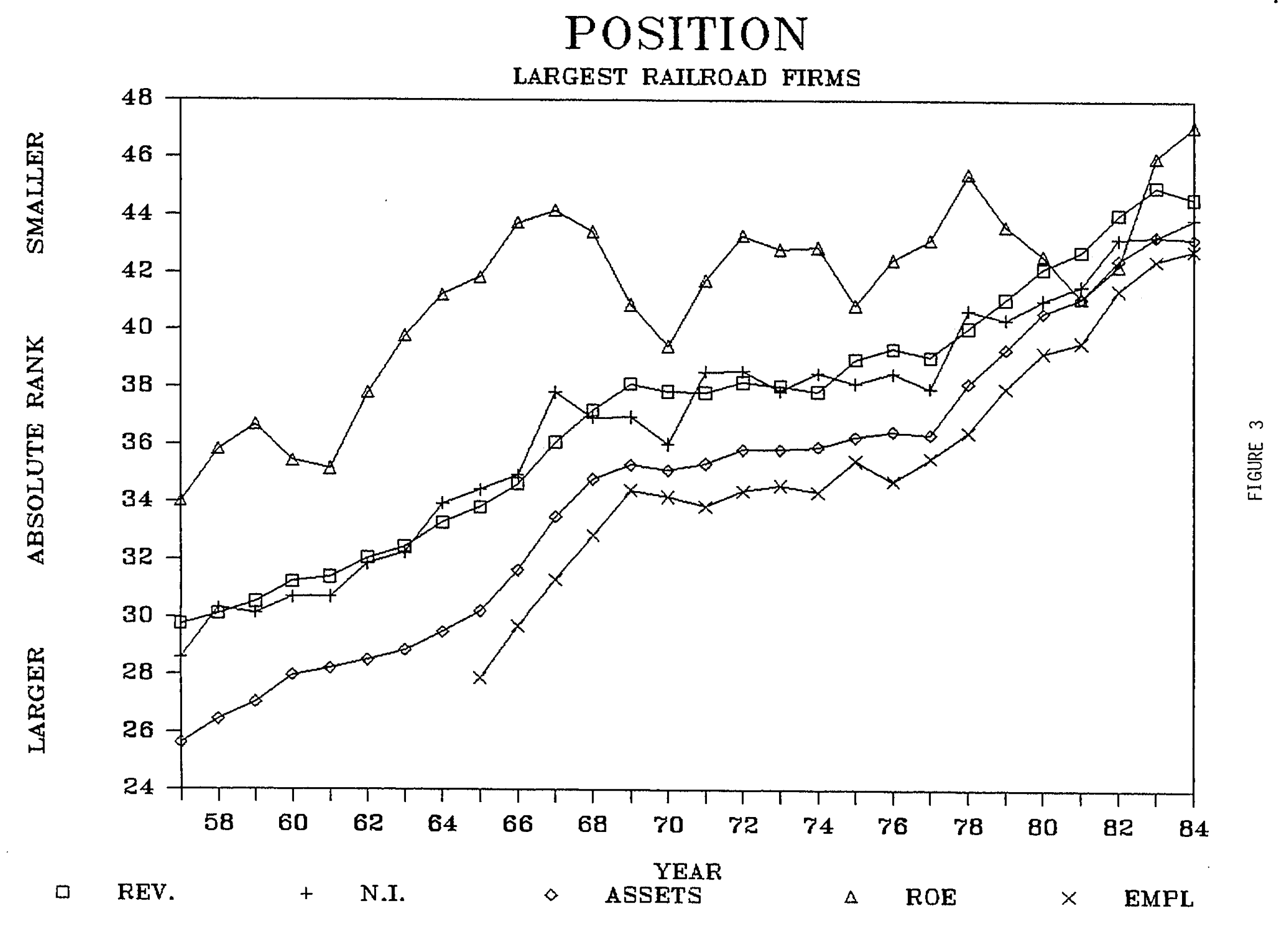




\section{VOLATILITY}

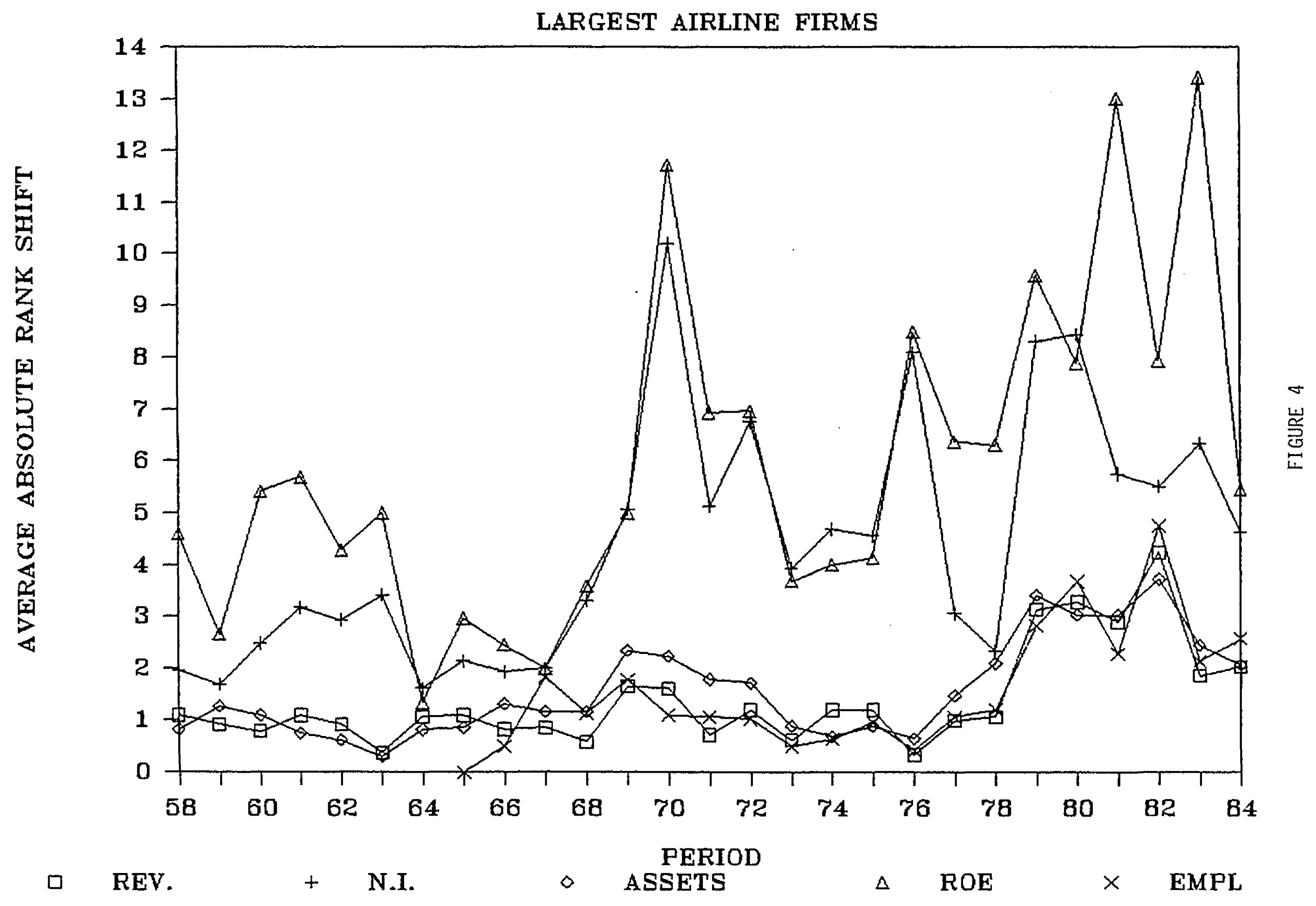




\section{POSITION}

\section{LARGEST AIRLINE COMPANIES}

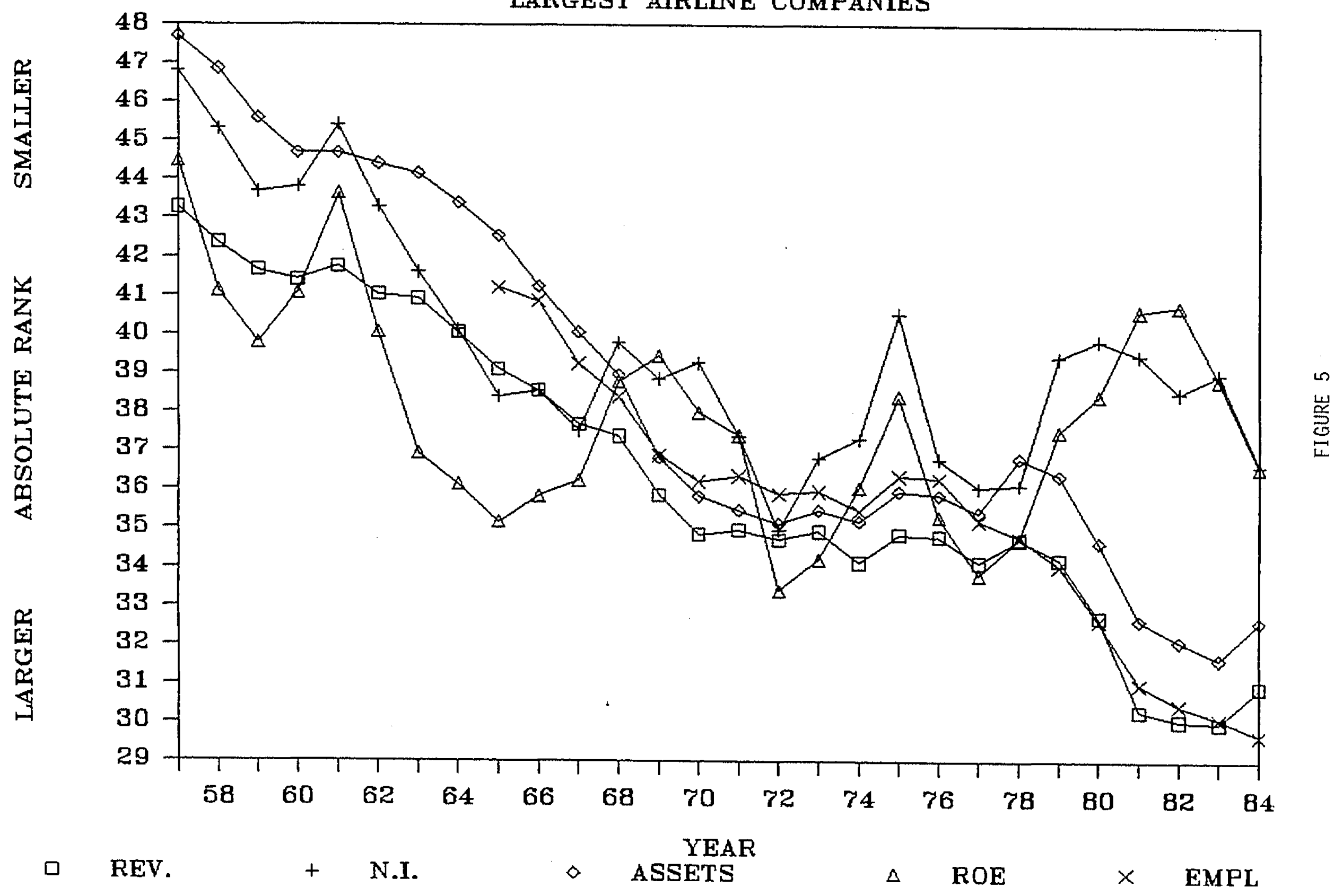




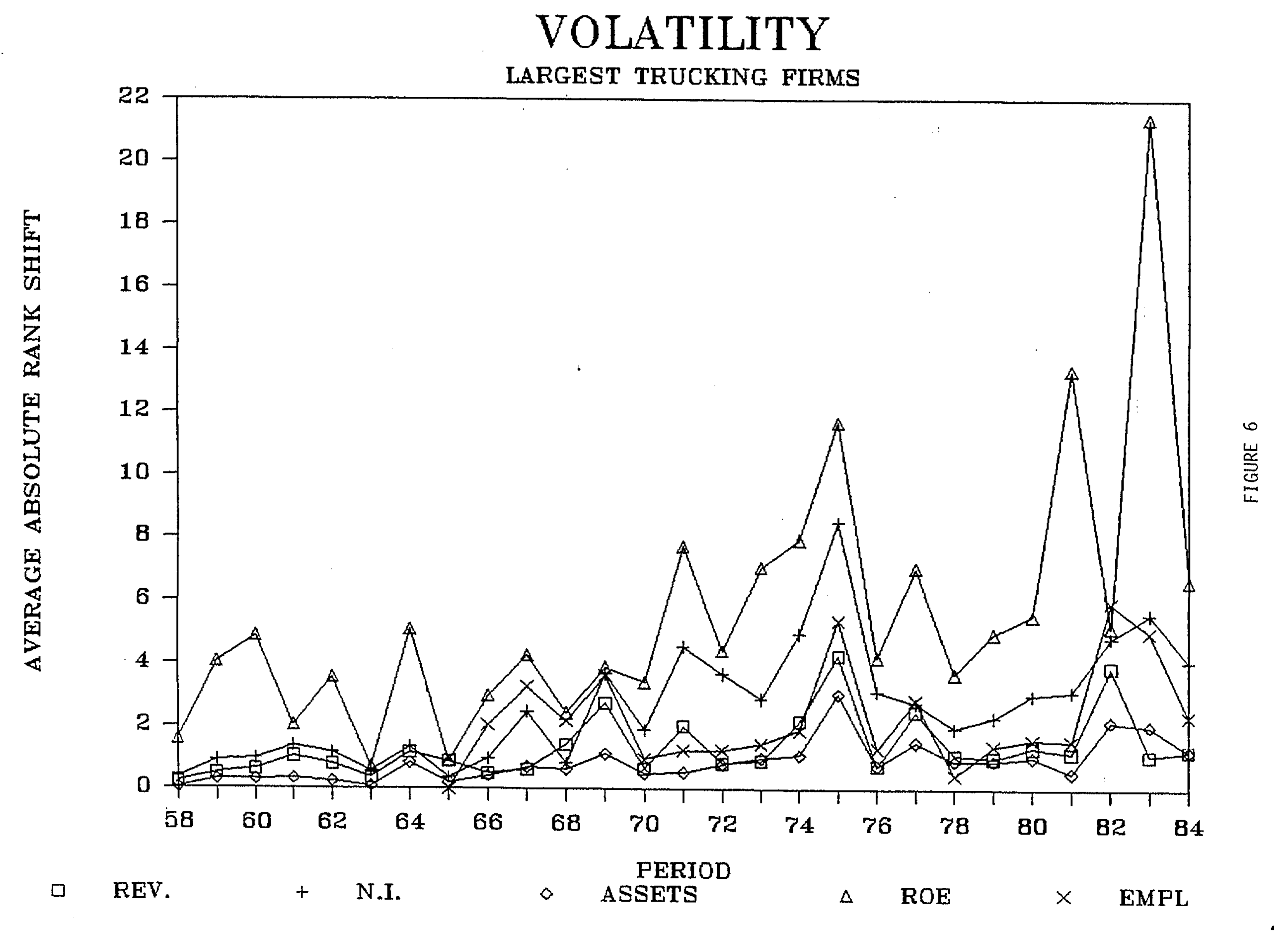




\section{POSITION}

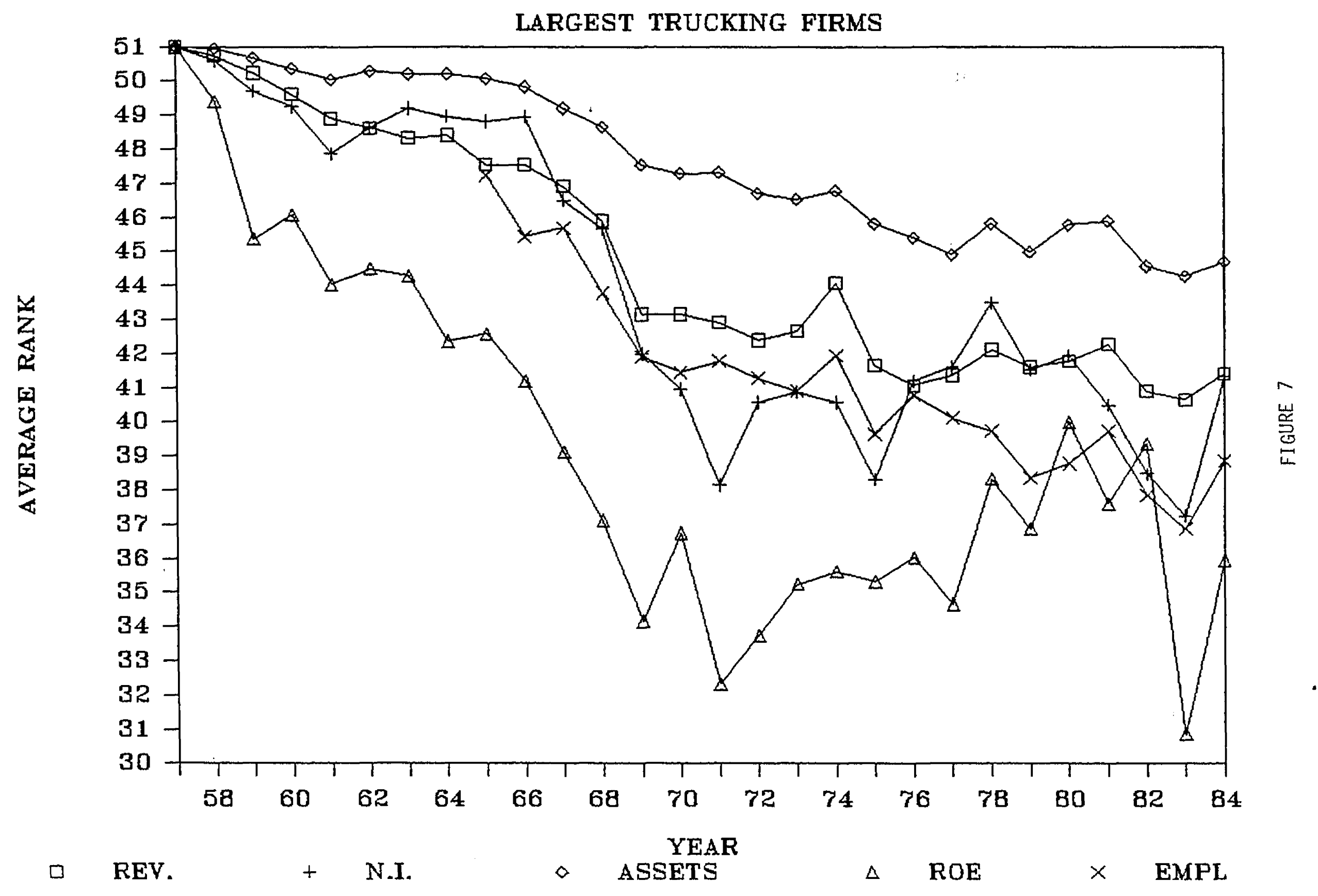




\section{POSITION}

\section{LARGEST PIPELINE FIRMS}

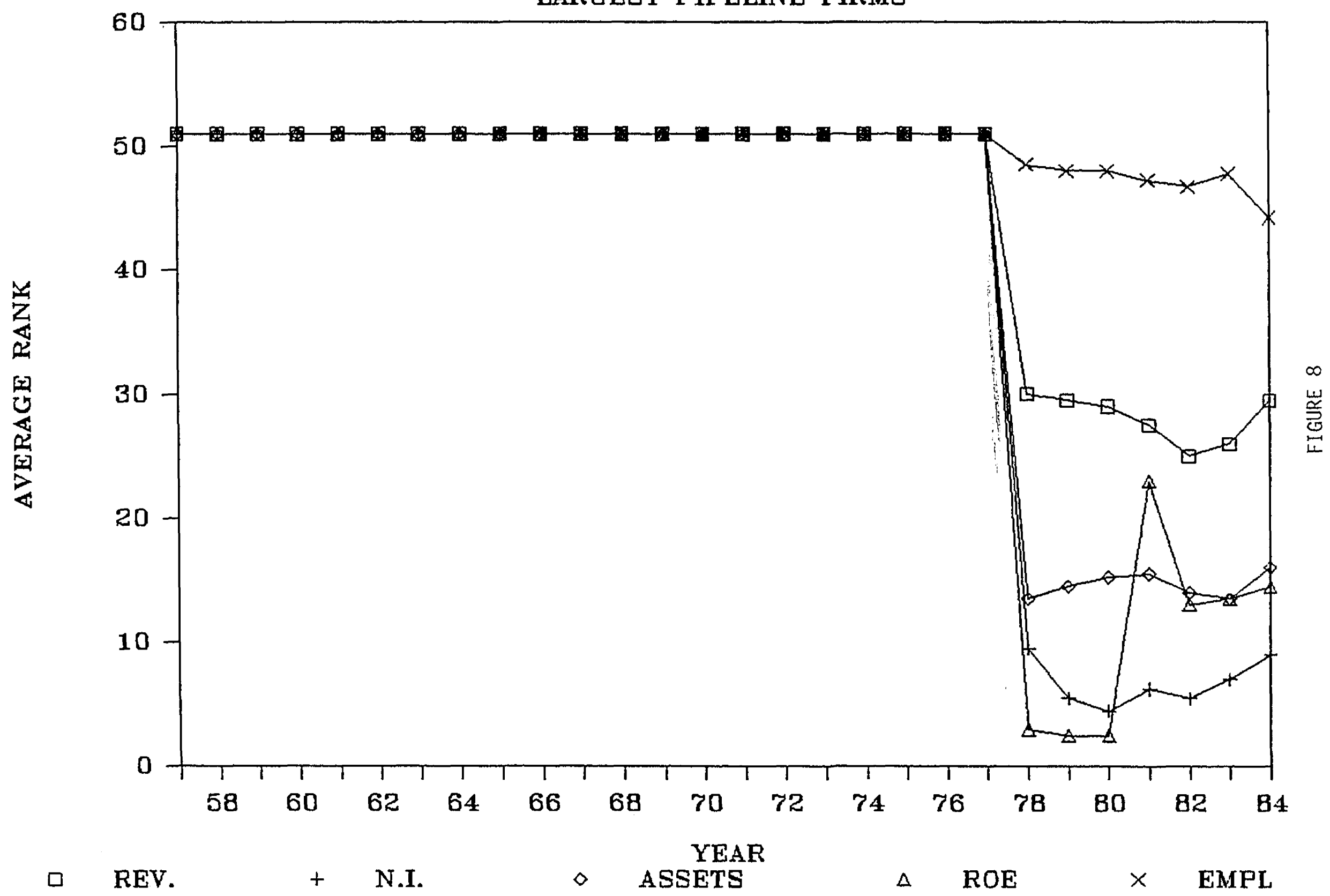




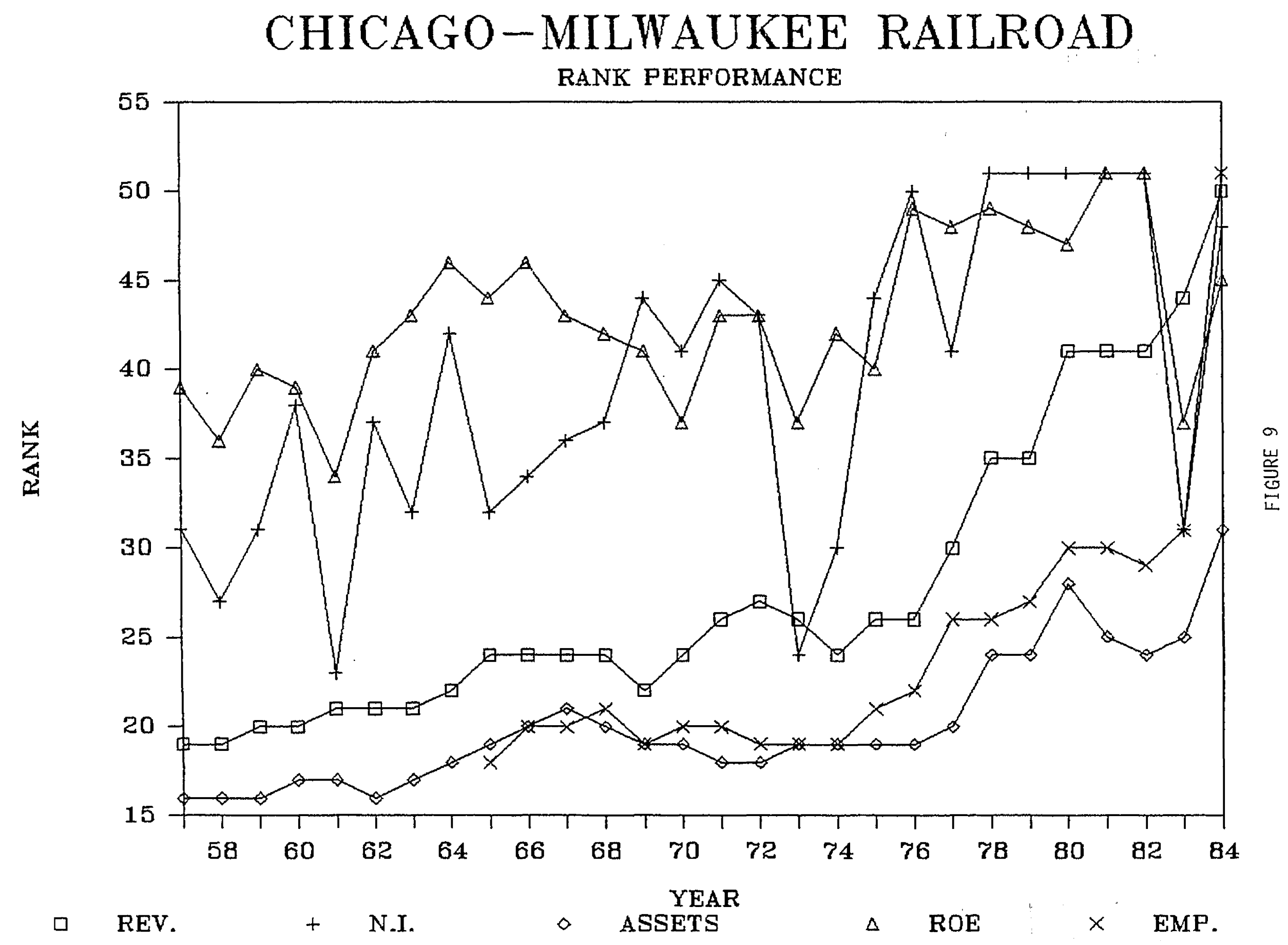




\section{SOUTHERN PACIFIC RAILROAD}

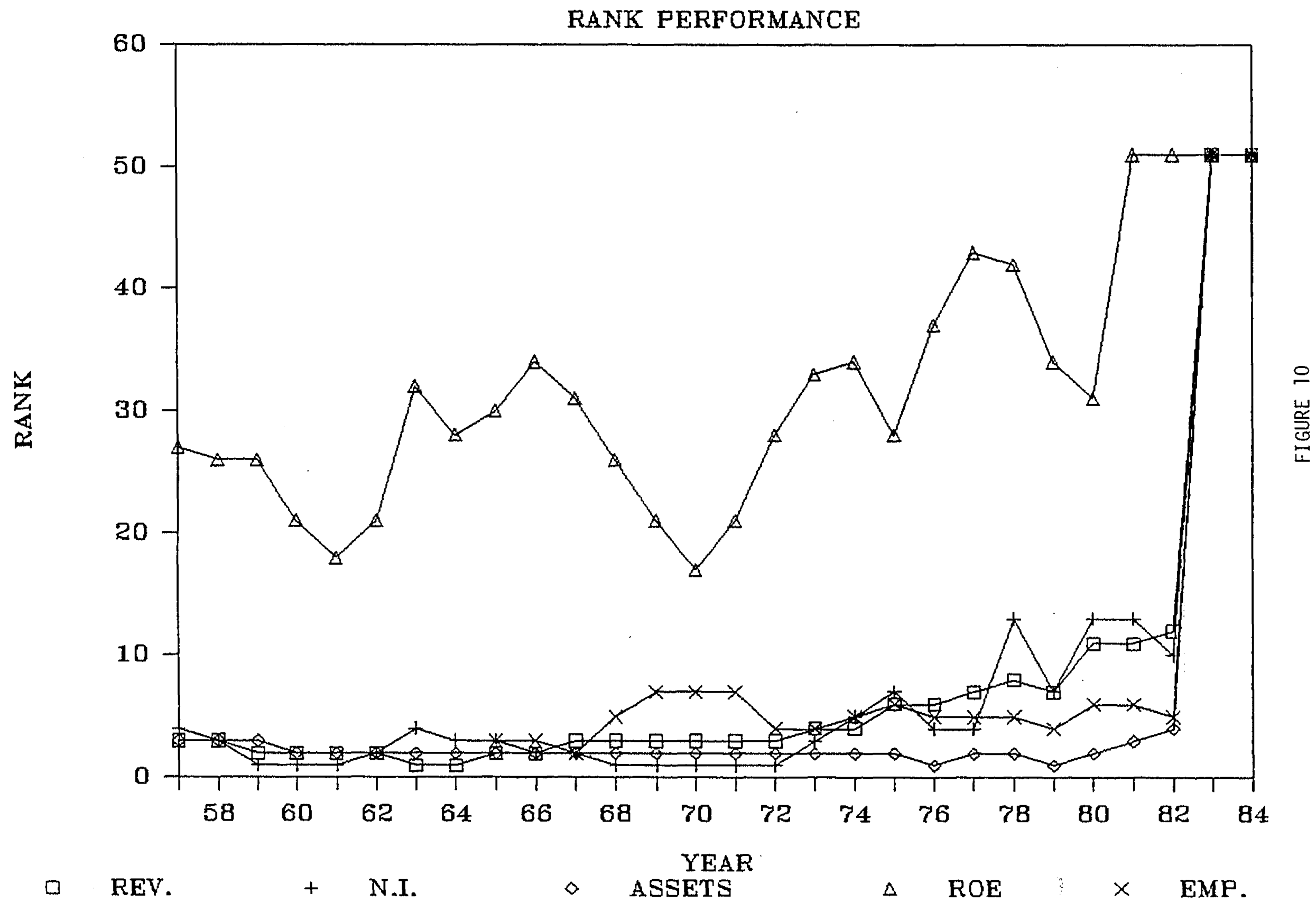




\section{CONSOLIDATED FREIGHTWAYS}

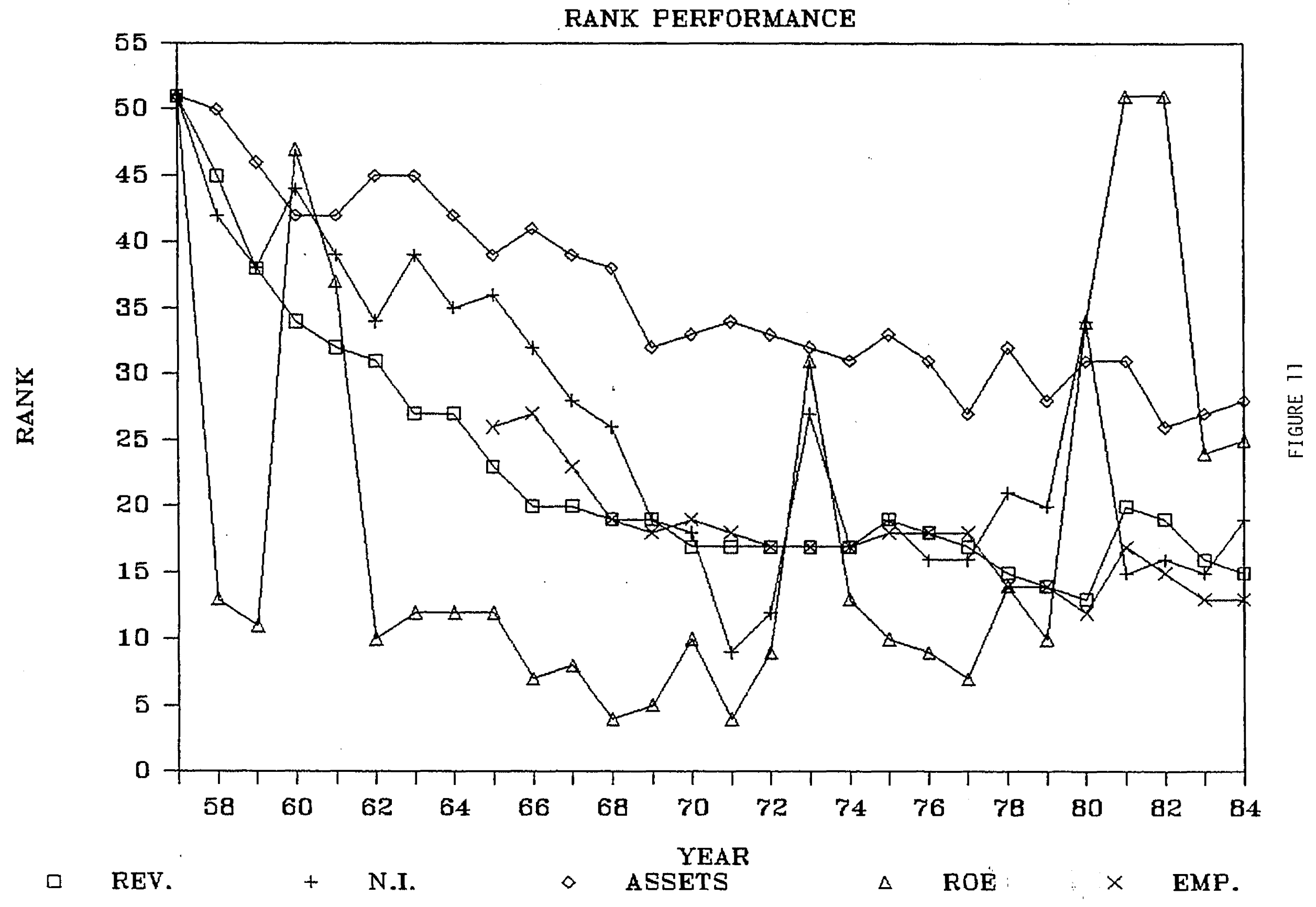




\section{ROADWAY EXPRESS}

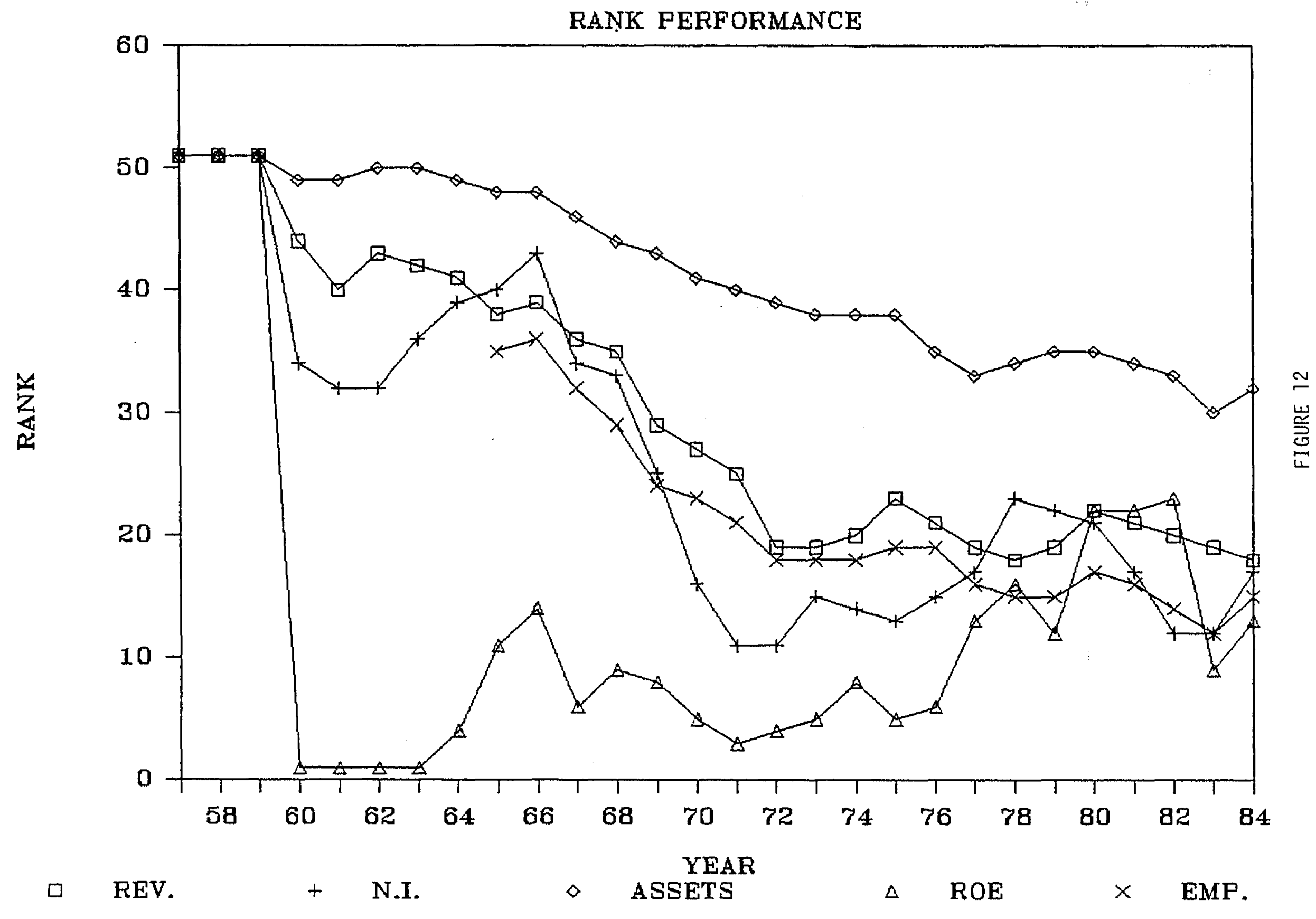




\section{UNITED PARCEL SERVICE}

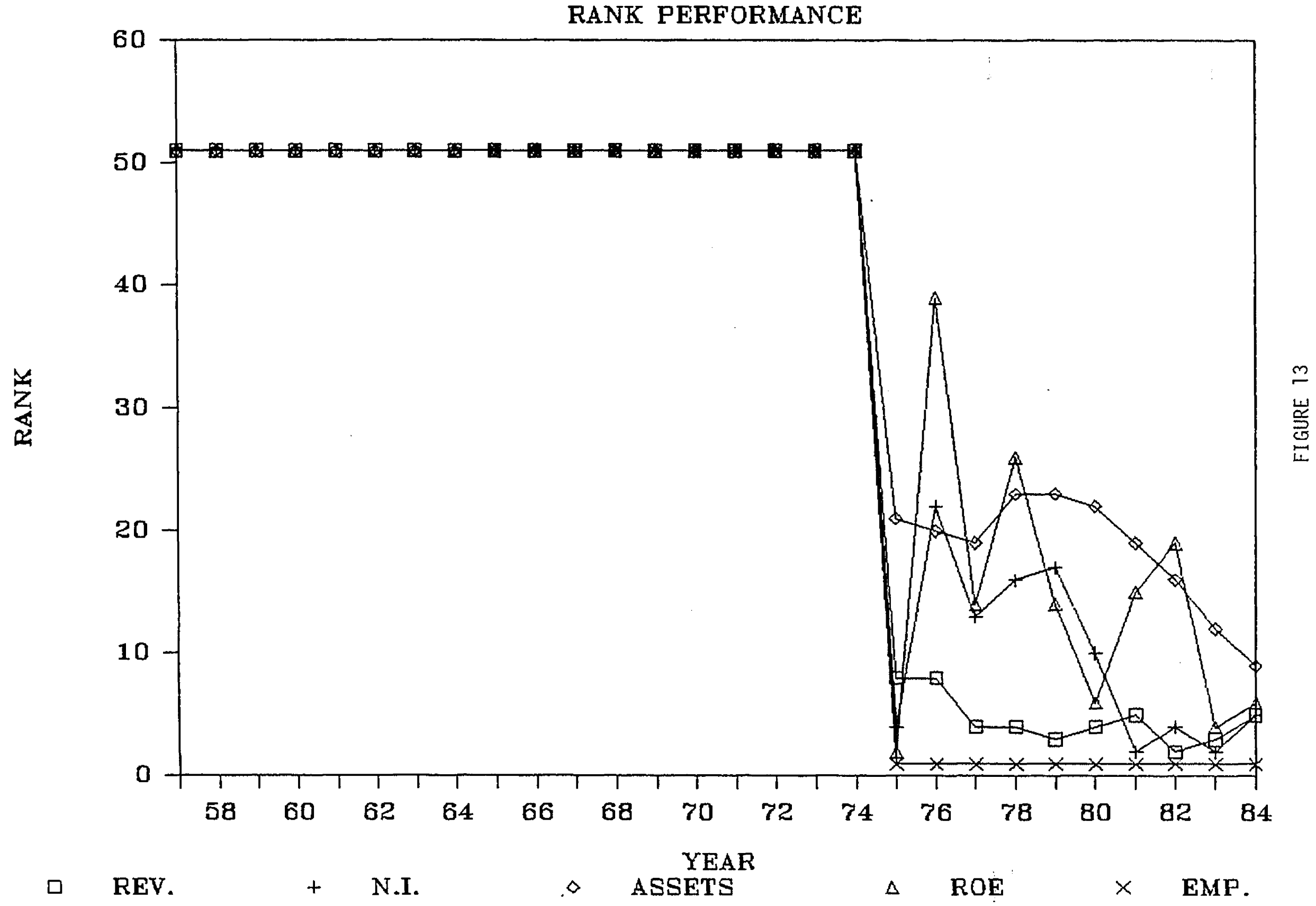




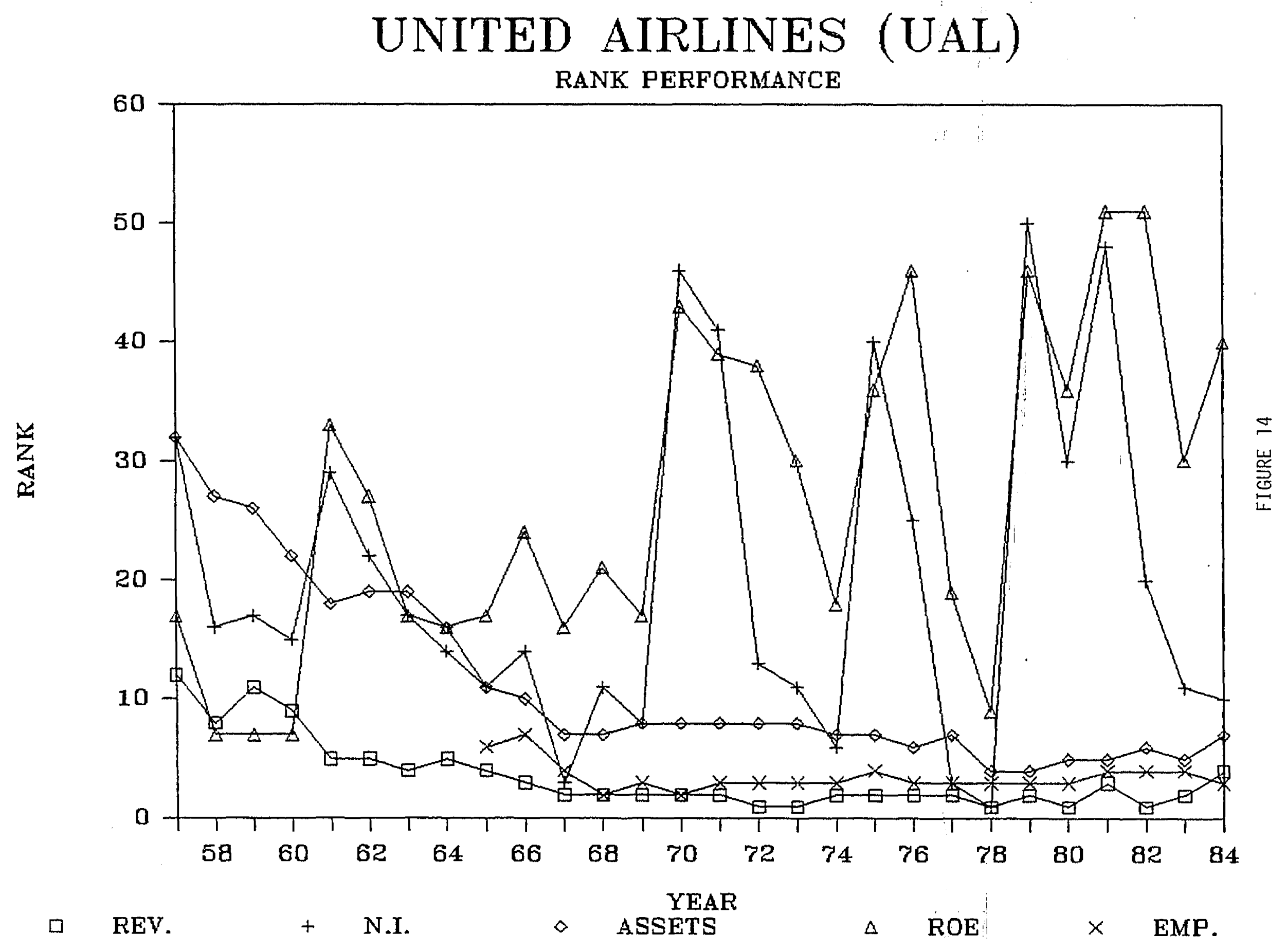




\section{NORTHWEST AIRLINES}

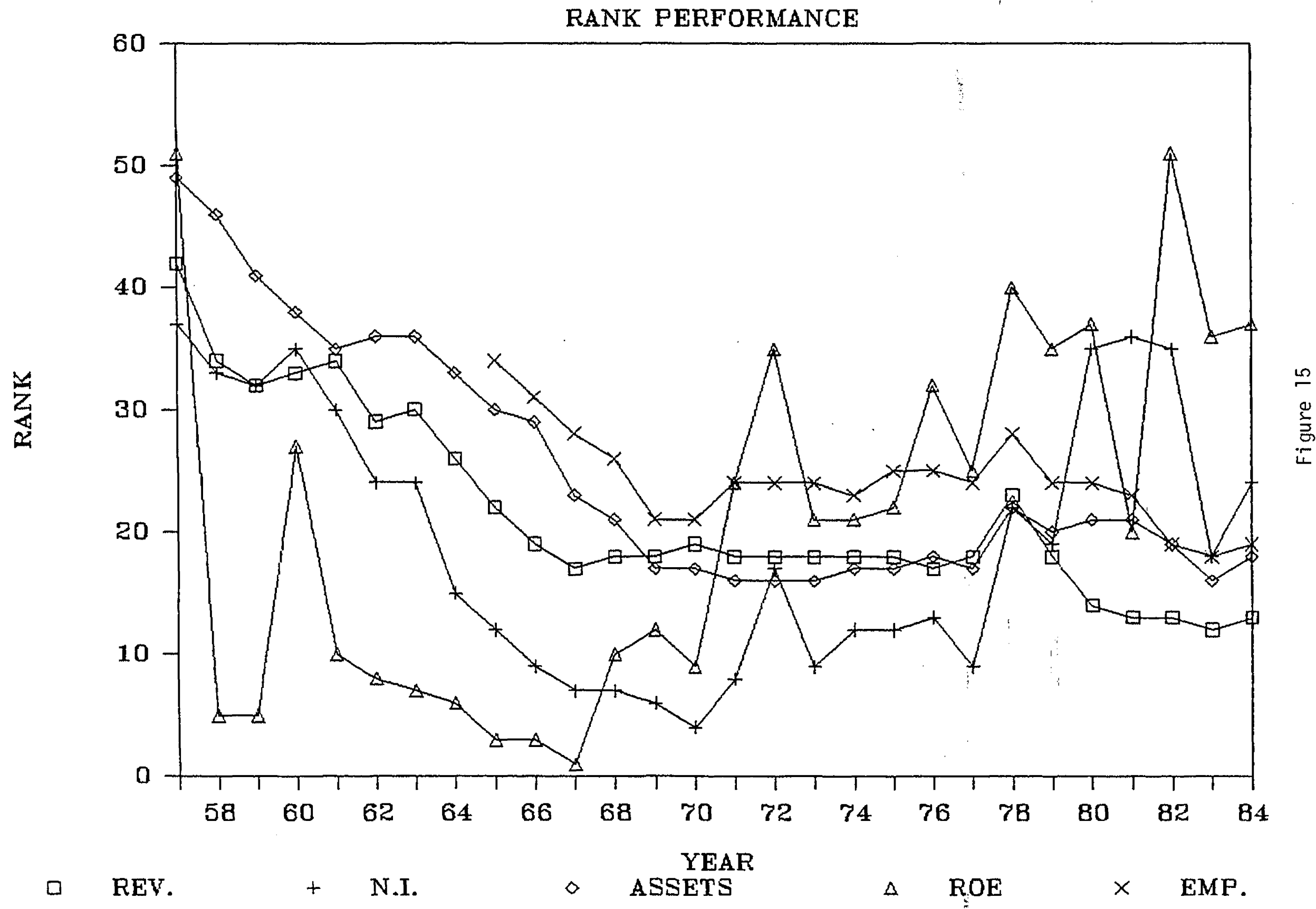


DELTA AIRLINES

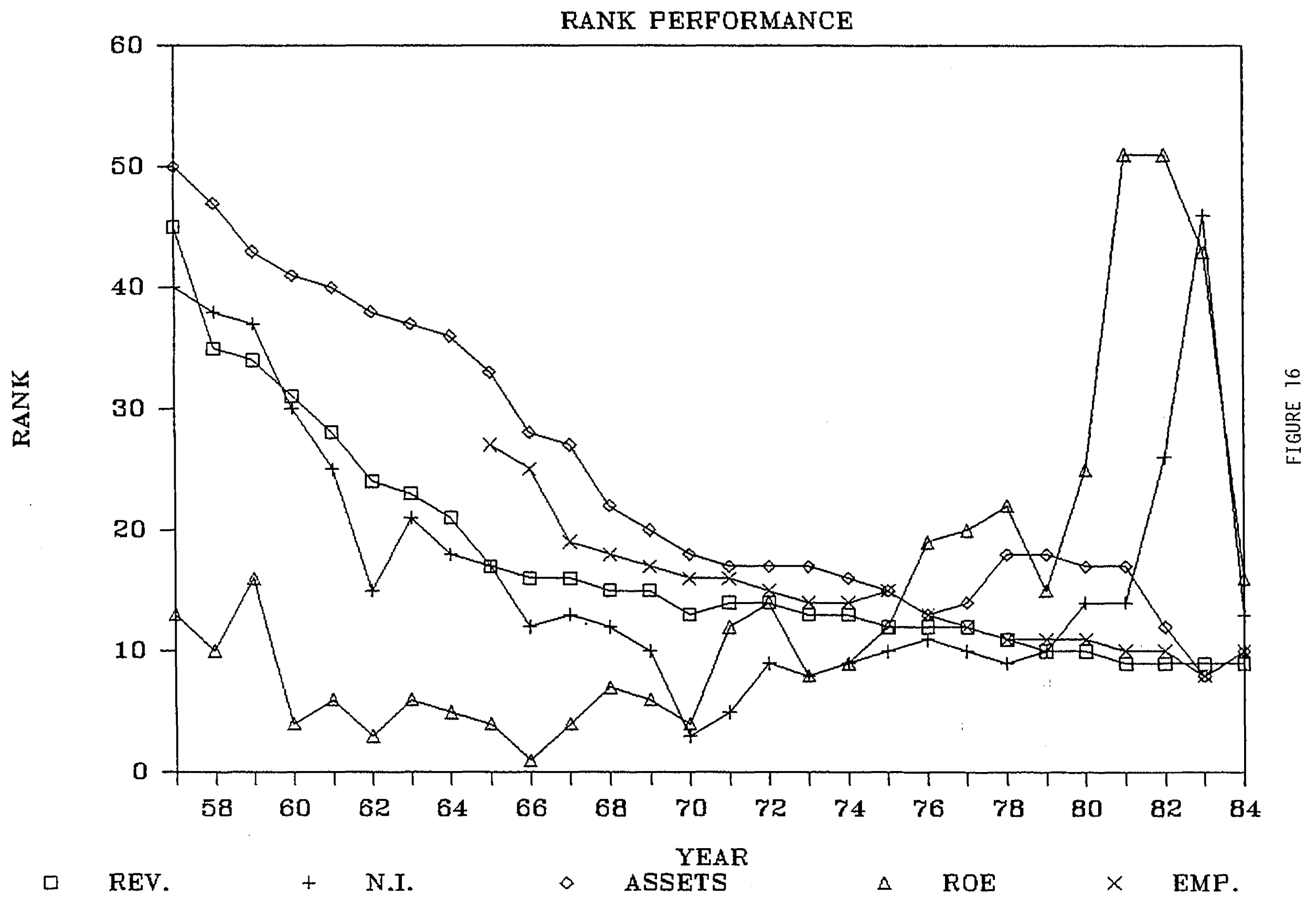




\section{AMERICAN AIRLINES}

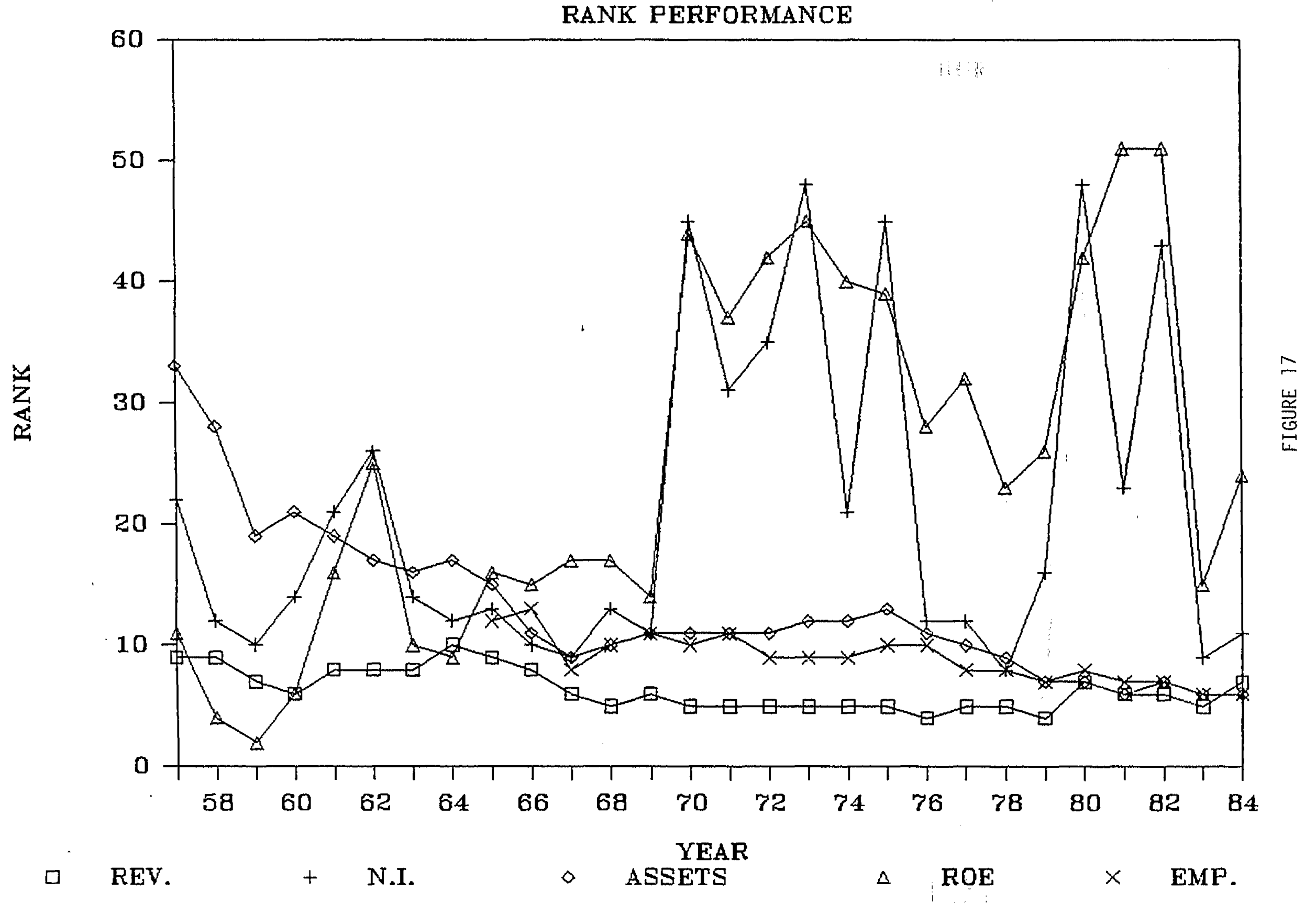




\section{PAN AMERICAN AIRLINES}

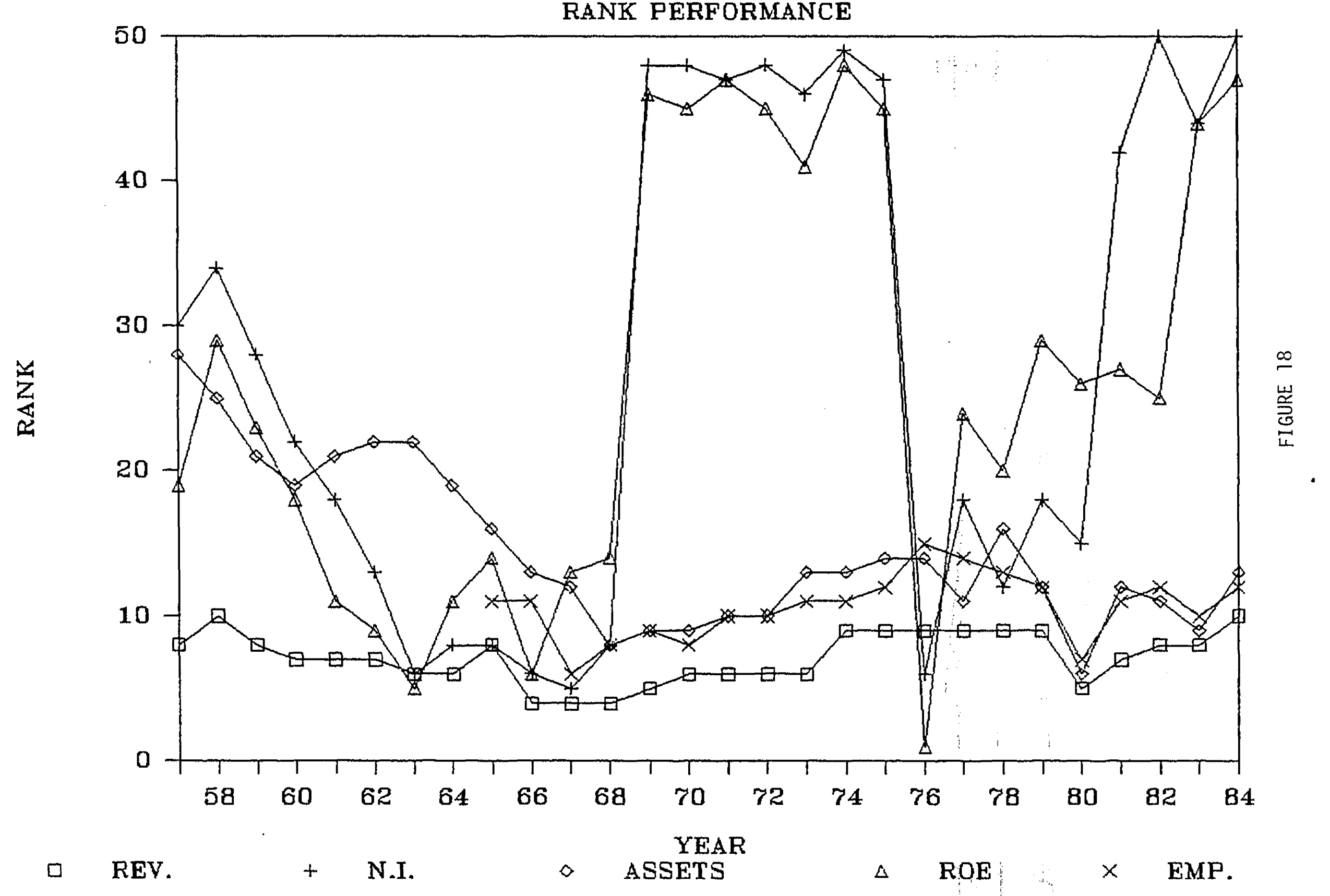

